Article

\title{
Techno-Environmental Evaluation of a Liquefied Natural Gas-Fuelled Combined Gas Turbine with Steam Cycles for Large Container Ship Propulsion Systems
}

\author{
Abdulaziz M. T. Alzayedi *, Suresh Sampath and Pericles Pilidis \\ School of Aerospace, Transport and Manufacturing, Cranfield University, Cranfield, Bedfordshire MK43 0AL, UK; \\ s.sampath@cranfield.ac.uk (S.S.); p.pilidis@cranfield.ac.uk (P.P.) \\ * Correspondence: Althayedi@gmail.com
}

check for updates

Citation: Alzayedi, A.M.T.; Sampath, S.; Pilidis, P. Techno-Environmental Evaluation of a Liquefied Natural Gas-Fuelled Combined Gas Turbine with Steam Cycles for Large Container Ship Propulsion Systems. Energies 2022, 15, 1764. https:// doi.org/10.3390/en15051764

Academic Editors: Piotr Folęga, Dorota Burchart and Andrea De Pascale

Received: 23 November 2021 Accepted: 24 February 2022 Published: 27 February 2022

Publisher's Note: MDPI stays neutral with regard to jurisdictional claims in published maps and institutional affiliations.

Copyright: (c) 2022 by the authors. Licensee MDPI, Basel, Switzerland. This article is an open access article distributed under the terms and conditions of the Creative Commons Attribution (CC BY) license (https:// creativecommons.org/licenses/by/ $4.0 /)$.

\begin{abstract}
Restrictions on emissions are being imposed by regional and international shipping organisations, which raise the question of which marine fuel and technology can most effectively replace heavy fuel oil and diesel engines. The aim of this study is to find appropriate advanced combined gas and steam turbine cycles for marine propulsion systems in a large container ship with respect to the evolving maritime environmental regulations. The selection criteria are the thermodynamic performance, emissions, size, and weight of advanced combined gas and steam turbine cycles in a large container ship. Two baselines are used: a diesel engine using marine diesel oil and a combined gas and steam turbine system using liquefied natural gas and marine diesel oil. Then, liquefied natural gas cycles are examined based on fuel replacement and enhanced to assess the benefits of liquefied natural gas over marine diesel oil. The results show that the enhanced liquefied natural gas combined gas and steam turbine cycles are the most efficient, at up to $1.6 \%$ higher than the other cycles. Regarding the size and weight, the combined gas and steam turbine propulsion system is approximately $24.7 \%$ lighter than the original diesel engine propulsion system.
\end{abstract}

Keywords: advanced combined gas and steam turbine cycle; techno-environmental; combined gas and steam turbine cycle; large container; ship; propulsion systems; liquefied natural gas; marine diesel oil; nitrogen oxide; carbon dioxide

\section{Introduction}

Diesel engines have dominated merchant ship propulsion for several decades. Approximately $96 \%$ of vessels that weigh over 100 gross tonnes and are used in civilian applications are powered by diesel engines [1]. Two-stroke diesel engines power large oil tankers, container ships, and ore carriers. Since the 1970s, land-based power plants have used combined-cycle gas and steam turbine systems. The use of such systems has been considered for ship propulsion systems. Only a few vessels have utilised CCGT for propulsion systems, such as Royal Caribbean's Radiance, Celebrity, Millennium and Infinity Cruises, and two Russian Ro-Ro ships. [2]. The authors believe that the fuel costs of this type of propulsion system is the main cause of its rarity. However, this is changing owing to environmental issues. The efficiency of CCGT can reach up to $60 \%$, which is higher than that of 2-stroke diesel engines [3]. The CCGT efficiency can be improved by enhancing the gas turbine cycles (top cycle) or the steam turbine cycles (bottom cycle). To enhance G.T. cycle efficiency, complex components such as a reheater, intercooler, or both can be integrated into the simple cycle. To increase the efficiency of the steam turbine cycles, a heat recovery steam generator with double or triple pressure should be used, and the steam turbine cycle should be reheated [4]. The key reasons for the prevalence of the two-stroke diesel engine are its high efficiency and ability to burn on low-cost heavy fuel oil. However, the drawbacks of 2-stroke diesel engines are related to the high levels of emissions contributed, such as nitrogen oxide, sulphur oxide, and particulate matter, 
which are currently the subject of continuously stricter regulations [5]. Some of these emissions result from the fuel that is used, whereas others depend on the engine cycle that is employed. Initially, the focus was on sulphur oxide and nitrogen oxide. More recently, environmental concerns have encompassed $\mathrm{CO}_{2}$ emissions, as stated by the International Maritime Organisation [6]. The IMO put forward measures for evaluating and controlling the energy efficiency design index values of new ships [7]. The $\mathrm{CO}_{2}$ emissions can be reduced by using a more efficient propulsion system or cleaner fuel (e.g., natural gas) [2]. In addition to the abovementioned environmental aspects and economic considerations related to fuel cost uncertainties, the researchers were encouraged to find a more efficient engine for marine propulsion systems. Among these solutions are those based on the concept of combined cycles (CCGT systems). Techno-environmental evaluations are essential studies that measure the technical performance and emission impacts of a technology. For various reasons and applications, CCGTs have been studied as propulsion systems for vessels, but few ships have been built with CCGT propulsion. The previous studies of CCGTs as propulsion systems for vessels are summarised in this section:

- Jefferson [8] studied the performance of a simple CCGT propulsion system under steady-state operation and transient periods, including acceleration, deceleration, and the impact of inlet air conditions. The heat recovery steam generator adopted in this study was a single-pressure generator. Therefore, the CCGT performance was affected by atmospheric conditions such as temperature, pressure, and relative humidity;

- Edwin [3] studied the cycle efficiency, specific fuel consumption, and boil-off gas of a simple CCGT fuelled by natural gas, in addition to a two-stroke diesel engine fuelled by heavy fuel oil for propulsion systems in liquefied natural gas ships. Additionally, they studied the emissions $\left(\mathrm{SO}_{X}, \mathrm{NO}_{X}\right.$, and $\left.\mathrm{CO}_{2}\right)$ and fuel consumption reductions in the CCGT. The results of this study demonstrated that CCGT propulsion is an attractive alternative for LNG ships. LNG permits a lower $\mathrm{CO}_{2}$ footprint (by approximately $20 \%$ ) because of its higher hydrogen content. Another fundamental advantage of natural gas fuel is that it delivers (in land applications) very low (25 ppm) amounts of NOx with appropriately designed combustors;

- Benvenuto [9] studied a simple CCGT fuelled by marine gas oil as an alternative to a two-stroke diesel engine fuelled by heavy fuel oil for the propulsion of a 9000 twenty-foot equivalent unit container ship. They investigated the performance of the powerplant and the efficiency of the design and high-load off-design conditions in both steadystate and dynamic situations, and determined the engine weight, dimensions, layout, capacity, and maintenance costs. The results revealed lower amounts of pollutant emissions from the CCGT plant than the two-stroke diesel engines. Furthermore, in terms of weight and dimensions, the two-stroke diesel engine had disadvantages compared with the CCGT with equivalent power. In terms of noise and vibration, the two-stroke diesel engine was much higher than the CCGT. The CCGT plant had a slight advantage over the two-stroke diesel engine in terms of engine efficiency. Additionally, the CCGT plant required significantly lower maintenance than a typical marine diesel engine. However, the costs of installation and operation still favoured the diesel engine;

- Benvenuto [10] also studied the performance of a CCGT with a marine gas turbine with a variety of steam turbine plants layouts, including single-pressure and dual-pressure HRSG layouts. The study results showed that the dual-pressure steam plant layout (with two boilers) had complex and high weights, dimensions, and costs, but had the best efficiency. The dual-pressure steam plant layout (with a single boiler) was less efficient. In terms of the complexity, weights, dimensions, and cost, the dual-pressure steam plant layout with one boiler was comparable to the dual-pressure steam plant layout with two boilers;

- Emmanuel-Douglas [11] analysed the performance of an optimal CCGT for cruise ships for $2000 \mathrm{~h}$ of operation and with various operating modes in terms of the vessel demands from power, electricity, and heat. The combined-cycle system consisted 
of a combined gas turbine electric and steam plant, CCGT turbines, a combined diesel-electric and gas turbine plant, a combined power and heat generation plant, and a diesel-electric plant with waste heat recovery. The results showed that the diesel engines show the best results compared with other propulsion systems in the cruise ship in terms of the economic aspects. Additionally, the flexibility of the gas turbine configuration enhanced the performance and made it appropriate for different applications;

- Altosole [2] studied a CCGT with single-pressure HRSG, CCGT with dual-pressure HRSG with a single boiler and CCGT with dual-pressure HRSG with two boilers in contrast to a conventional 2-stroke diesel engine as a prime mover in a 9000 TEU unit large containership. He studied the 2-stroke diesel engine with waste heat recovery as a prime mover in an oil tanker vessel and investigated the performance, emissions, and economic aspects along with the weight and dimensions of all propulsion systems. The results showed that the efficiency levels of the dual-pressure steam plant with two boilers was $1.3 \%$ and $2.3 \%$ better when compared with the dual-pressure (single boiler) and single-pressure steam plant, respectively. Moreover, the CCGT plant was smaller, and its components weighed less than those of the two-stroke diesel engine. However, it was 20-40\% more expensive. The CCGT exhibited an $8 \%$ reduction in specific fuel consumption over the two-stroke diesel engine.

To date, only a limited number of studies have performed techno-environmental evaluations of advanced CCGT systems for large container ships. Hence, this study contributes two aspects:

1. Based on the literature review, the following concepts for marine propulsion systems were studied:

- The use of enhanced LNG cycles with cryogenic qualities to improve CCGT efficiency;

- A comprehensive environmental assessment to measure the emissions of NOX and $\mathrm{CO}_{2}$ from the presented CCGT cycles and a two-stroke diesel engine.

2. For these particular cycles, other analytical aspects were brought together for the first time using existing algorithms:

- A technical assessment was performed on the CCGT cycles, simple combined gas turbine-steam system, reheat combined gas steam turbine, and the intercoolerreheat combined gas steam turbine with a single HRSG fuelled by MDO and LNG as propulsion systems in a large container ship;

- The possibility of positing the intercooler and reheater was assessed, which can significantly affect the engine output and efficiency;

- A method and model for the sizing and weighting of advanced CCGT cycles for the large container ship was proposed.

The remainder of this paper is as follows. The second section describes the methods employed in this study. The third section defines the assumptions, simulation, and validation of the method. The fourth section provides the results and discussion, and the conclusion is presented in the fifth section.

\section{Materials and Methods}

The methodology for this research is divided into four stages, as shown in Figure 1. Stage one represents the gas turbine models evaluated using an in-house gas turbine performance software (Turbomatch) [12], which was built to simulate the three types of gas turbine cycles with different overall pressure ratios, turbine entry temperature (TET) values, and ambient temperatures. These three gas turbine cycles are:

1. Simple cycle fuelled by LNG and MDO;

2. Complex cycles incorporating reheating and intercooling fuelled by LNG and MDO;

3. Enhanced LNG benefitting from LNG's cryogenic properties. 


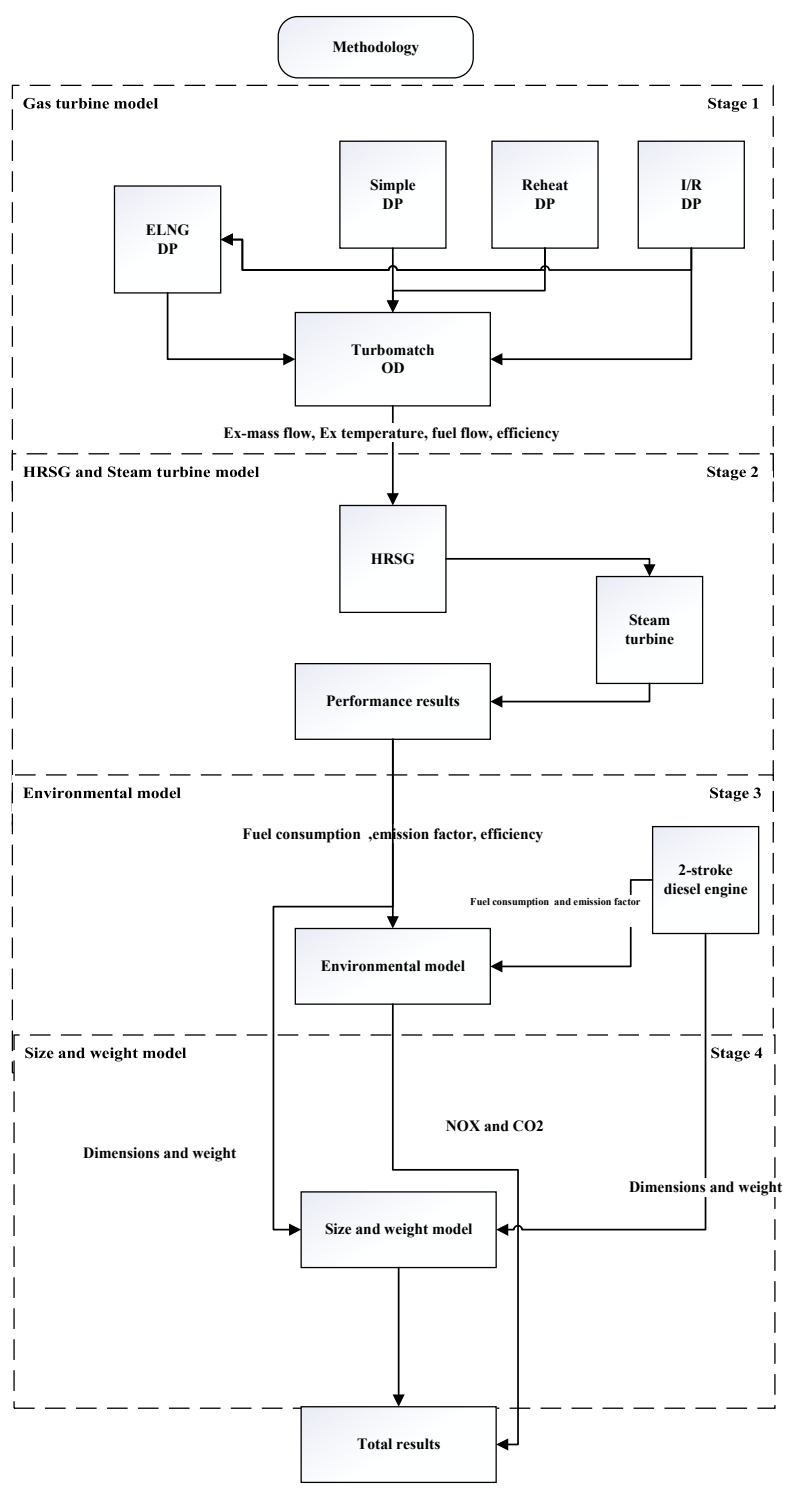

Figure 1. Flowchart of the methodology employed in this study. $\mathrm{NOx}$ : Nitrogen oxide; $\mathrm{CO}_{2}$ : carbon dioxide; CCGT: combined-cycle gas turbine (with steam); I/R: intercooler-reheat cycle; HRSG: heat recovery steam generator; ELNG: enhanced liquefied natural gas.

The results of this model, which will be the exhaust mass flow, exhaust temperature, fuel flow, and efficiency of all cycles, will be the inputs for stage two. Stage two presents two models: the HRSG and steam turbine, which were constructed using the MATLAB software to simulate the CCGT performance with different inlet conditions from stage 1. Stage three presents the environmental model, which assesses the $\mathrm{NO}_{\mathrm{X}}$ and $\mathrm{CO}_{2}$ emissions from the fuel flows and emission factors of all CCGT and two-stroke diesel engines. The final stage evaluates the size and weight of all CCGT cycles and two-stroke diesel engines in a large container ship based on the dimensions and weight.

\subsection{Combined-Cycle (CCGT) Model}

The exhaust heat from the gas turbine increases the power and efficiency of the CCGT. Figure 2 shows the CCGT layout. 


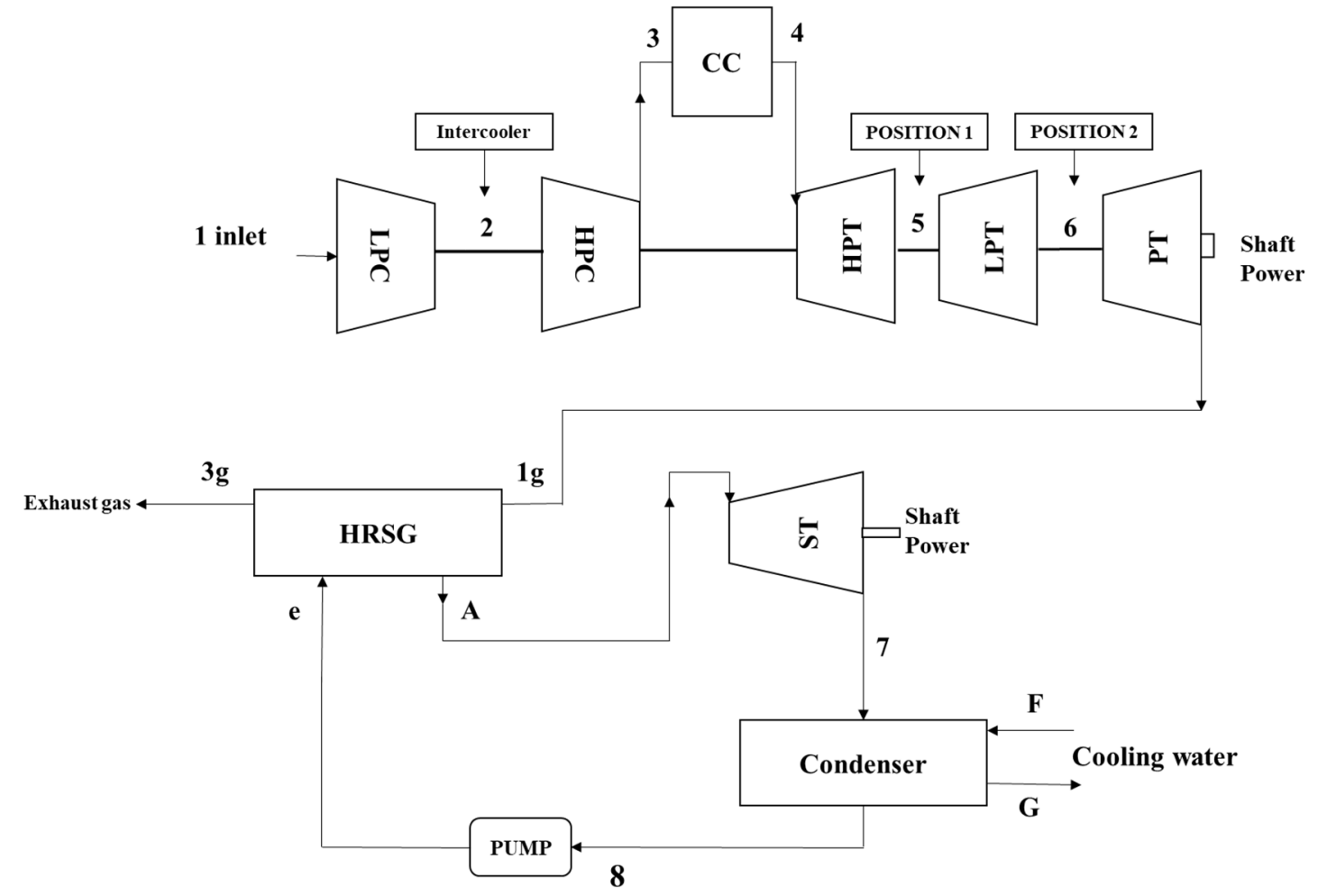

Figure 2. Flowchart of the CCGT model. HPT: high-pressure turbine; LPT: low-pressure turbine; P.T.: power turbine; HRSG: heat recovery steam generator; 1: inlet air mass flow temperature to low-pressure compressor; 2: outlet air mass flow temperature from low-pressure compressor to highpressure compressor; 3: outlet air mass flow temperature from high-pressure compressor and inlet air mass flow to combustor; 4: outlet air-fuel mass flow temperature from combustor to high-pressure turbine; 5: outlet air-fuel mass flow temperature from high-pressure turbine to low-pressure turbine; 6: outlet air-fuel mass flow temperature from low-pressure turbine to power turbine; 1g: exhaust air-fuel mass flow temperature from gas turbine to HRSG; 3g: exhaust air-fuel mass flow temperature from HRSG; A: outlet steam mass flow temperature from HRSG to steam turbine; 7: outlet steam mass flow temperature from steam turbine to condenser; 8: outlet water mass flow temperature from condenser to the pump; e: outlet water mass flow temperature from pump to HRSG.

The model for the CCGT was used to calculate the engine design point parameters and predict the off-design performance using MATLAB. A steam model with a single HRSG assumption was based on the optimal steam cycle parameters obtained from previous studies $[2,10]$.

\subsubsection{Gas Turbine Model}

A performance model of the gas turbine was developed using the Cranfield in-house gas turbine performance software (Turbomatch) [12]. The software could model the designpoint and off-design aspects of gas turbine cycles for any engine configuration. This study explores simple, reheat, and intercooler-reheat marine gas turbines that have a CCGT. The marine gas turbine used here was a two-shaft marine gas turbine with a power turbine. The simulation reference point for the G.T., inspired by the RB211 [13], was a gas turbine used extensively in offshore applications. The analysis was based on the published data for existing commercial gas turbines. Derived cycles were selected for simple, reheat, and intercooler-reheat (I/R) cycles, which allowed us to select the optimal locations for the reheater and intercooler to be implemented along with the simple cycle [14]. Simple, reheater, and I/R systems had the same D.P. in TET and output power to ensure a fair examination of these cycles for CCGT; the ELNG cycle was higher than TET $=+50 \mathrm{~K}$ owing to its good characteristics. Because of the salinity of marine environments, the adopted TET 
values were much lower than those of state-of-the-art gas turbines used in land applications. Thus, the overall efficiencies obtained were typically $5 \%$ lower than the values of 0.60 or $-0.60+$ verified in modern cycles. Nonetheless, these efficiencies were very competitive.

\section{- D.P. matching calculation of the gas turbine}

The model inspired by the RB211-6762 GT is used to calibrate the engine D.P. parameters and predict the off-design performance. The target performance parameters for the D.P. simulation are the thermal efficiency, exhaust gas temperature (EGT), and exhaust mass flow that will influence the CCGT.

- Simple, reheat, I/R, and ELNG cycles for D.P. and Off-Design Performance Prediction

After verification, the model with the actual engine will modify the model to obtain the output power needed at D.P. The D.P. will increase the pressure ratio from 20 to 60 . The D.P. for the reheat cycle will be obtained by choosing the best location for reheating to achieve the optimal efficiency with an exhaust temperature of $600{ }^{\circ} \mathrm{C}$ by changing the overall pressure ratio. The position of the reheater will influence the reheating between the high-pressure turbine (HPT) and low-pressure turbine (LPT) in position 1, as well as between the LPT and power turbine (P.T.) in position 2. The D.P. for the I/R will be obtained by selecting the best locations for the intercooler and reheater to achieve the optimal efficiency with an exhaust temperature of $600^{\circ} \mathrm{C}$ by changing the overall pressure ratio. After choosing the best cycles for a gas turbine at the D.P., the off-design performance of CCGT will be subsequently predicted for a variety of different scenarios, such as when the TET changes from 1500 to $1800 \mathrm{~K}$, or for the effect of ambient temperature, which ranges from -20 to $45^{\circ} \mathrm{C}$ with different fuels (LNG and MDO were considered in this study). The calculations used for changing ambient temperatures are off-design calculations carried out with Turbomatch, the Cranfield performance evaluation code. Turbomatch can perform design point, off-design, transient, and degraded G.T. calculations. For more realistic results, the exhaust temperature from the gas turbine will be as follows:

1. If EGT < $873 \mathrm{~K}$, steam cycle $\mathrm{T}=\mathrm{EGT}-$ pinch point difference;

2. If EGT $>873 \mathrm{~K}$, steam cycle $\mathrm{T}=873-$ pinch point difference (i.e., constant).

\subsubsection{HRSG Model}

A single-pressure HRSG is adopted here as a standard type for the combined-cycle gas turbine power plant. A single-pressure HRSG with economiser, evaporator, and superheater sections is utilised for the generation of the superheated process steam. The temperature profile of the HRSG and heat balance is shown in Figure 3.

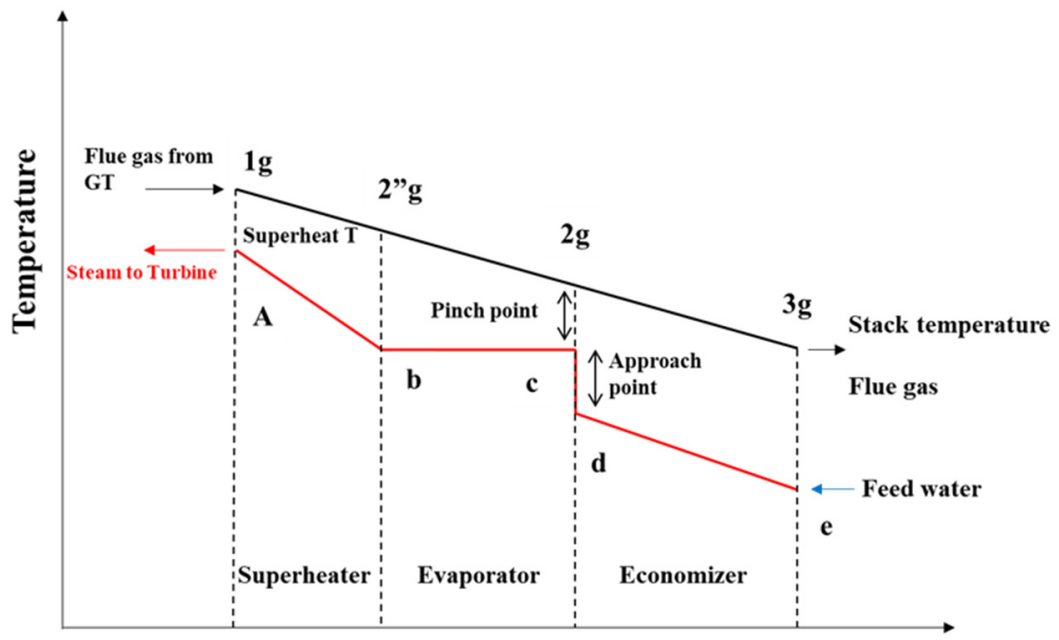

Figure 3. Temperature diagram of the heat recovery steam generator (HRSG); A: outlet steam mass flow temperature from HRSG to steam turbine; $b$ and $c$ : temperature of the steam inlet and outlet the evaporator; $\mathrm{d}$ : outlet fluid mass flow temperature from economizer. 
The thermal investigation of the HRSG depends on the approach point $\left(\mathrm{T}_{\mathrm{ap}}\right)$ and pinch point $\left(\mathrm{T}_{\text {pin }}\right)$, which contribute to the effectiveness of the heat exchange. The approach point $\left(\mathrm{T}_{\mathrm{ap}}\right)$ is the difference between the water temperature entering the evaporator and the saturation temperature. The pinch point $\left(\mathrm{T}_{\mathrm{pin}}\right)$ is the temperature difference between the hot and cold fluids. The first step in the process is to determine the temperature profile. The temperatures of the working fluid and exhaust gases at the inlet and outlet for each section can be calculated using the energy balance. The equation used to create the temperature profile is the heat balance equation:

$$
\mathrm{Q}_{1-3}=\mathrm{Q}_{\mathrm{A}-\mathrm{e}}
$$

where $Q_{1-3}$ is the heat along with the exhaust gases from the gas turbine and $Q_{A-e}$ is that along with the steam from the steam turbine.

The temperature of the steam exiting the evaporator is:

$$
\mathrm{T}_{\mathrm{b}}=\mathrm{T}_{\mathrm{c}}
$$

where $T_{c}$ is the saturation steam temperature at superheater pressure. The temperature of the gas leaving the superheated is:

$$
\mathrm{T}_{2 \mathrm{~g}}=\mathrm{T}_{\text {pin }}+\mathrm{T}_{\mathrm{C}}
$$

The temperature of the water inlet the evaporator is:

$$
\mathrm{T}_{\mathrm{d}}=\mathrm{T}_{\mathrm{c}}-\mathrm{T}_{\mathrm{ap}}
$$

We apply the energy balance between the gas and steam to find the steam mass flow $\mathrm{m}_{\mathrm{s}}$ :

$$
\mathrm{Q}_{1-2}=\mathrm{C}_{\mathrm{p}} \times \mathrm{m}_{\mathrm{g}} \times\left(\mathrm{T}_{1 \mathrm{~g}}-\mathrm{T}_{2 \mathrm{~g}}\right)=\mathrm{Q}_{\mathrm{A}-\mathrm{c}}=\mathrm{m}_{\mathrm{s}}\left(\mathrm{h}_{\mathrm{A}}-\mathrm{h}_{\mathrm{c}}\right)
$$

where $m_{g}$ is the exhaust mass flow from the gas turbine, $T_{1 g}$ is the exhaust tempreture from gas turbine, $h_{A}$ is the enthalpy from temperature at A stagnation, and $h_{c}$ is the enthalpy from temperature at c stagnation.

The temperature of the hot exhaust gases exiting the HRSG can be found by considering the energy balance between states 1 and 3:

$$
\mathrm{m}_{\mathrm{s}}\left(\mathrm{h}_{\mathrm{a}}-\mathrm{h}_{\mathrm{e}}\right)=\mathrm{C}_{\mathrm{p}} \times \mathrm{m}_{\mathrm{g}} \times\left(\mathrm{T}_{1 \mathrm{~g}}-\mathrm{T}_{3 \mathrm{~g}}\right)
$$

where $h_{e}$ is the enthalpy from the temperature at e stagnation with the pump pressure.

\subsubsection{Steam Turbine Model}

The steam at high temperature and high pressure obtained from the HRSG expands to the condenser pressure in the steam turbine. The power generated by the steam turbine is:

$$
\mathrm{w}_{\mathrm{s}}=\mathrm{m}_{\mathrm{s}}\left(\mathrm{h}_{\mathrm{A}}-\mathrm{h}_{7}\right)
$$

where $h_{7}$ is the enthalpy from the temperature of the steam at the exhaust steam turbine.

\subsubsection{Condenser Model}

The heat rejected from the condenser is:

$$
\mathrm{Q}_{\text {cond }}=\mathrm{m}_{\mathrm{s}}\left(\mathrm{h}_{7}-\mathrm{h}_{8}\right)
$$

where $h_{8}$ is the enthalpy of the fluid at the condenser pressure. 


\subsubsection{Pump Model}

The pump extracts the condensate, which is raised to the economiser pressure. The corresponding process is given by:

$$
\mathrm{w}_{\mathrm{p}}=\mathrm{m}_{\mathrm{s}}\left(\mathrm{h}_{8}-\mathrm{h}_{\mathrm{e}}\right)
$$

Therefore, the total power for the steam turbine plant is:

$$
\mathrm{w}_{\mathrm{T}}=\mathrm{w}_{\mathrm{S}}-\mathrm{w}_{\mathrm{P}}
$$

The overall thermal efficiency for the CCGT is:

$$
\eta=\frac{\mathrm{w}_{\mathrm{T}}+\mathrm{w}_{\mathrm{GT}}}{\mathrm{Q}_{\mathrm{in} \mathrm{GT}}}
$$

where $\mathrm{w}_{\mathrm{T}}$ is the total power from the steam turbine, $\mathrm{w}_{\mathrm{GT}}$ is the power from the gas turbine, and $\mathrm{Q}_{\mathrm{in}} \mathrm{GT}$ is the heat input in the gas turbine.

\subsection{ELNG Cycle}

In the long term, CCGT cycles benefitting from the cryogenic properties unique to LNG may be implemented. LNG is assumed to be stored as a saturated liquid at atmospheric pressure. In the investigation described here, two enhancements are included. The first relates to the gasification of the fuel. The energy required to gasify the LNG is provided in a heat exchanger where the gas turbine inlet air is cooled. This permits the gas turbine to operate with a lower inlet temperature. An energy balance process is carried out where the cooled fluid is the gas turbine inlet air and the heated fluid is the fuel flow. The fuel flow changes phase and emerges at a temperature $15 \mathrm{~K}$ lower than the air inlet temperature. The natural gas used is assumed to be pure methane. The gas turbine inlet air is assumed to experience a pressure loss of 3\%. Figure 4 shows the ELNG cycle layout. Figure 5 show the heat balance in the heat exchanger between the LNG and inlet air.

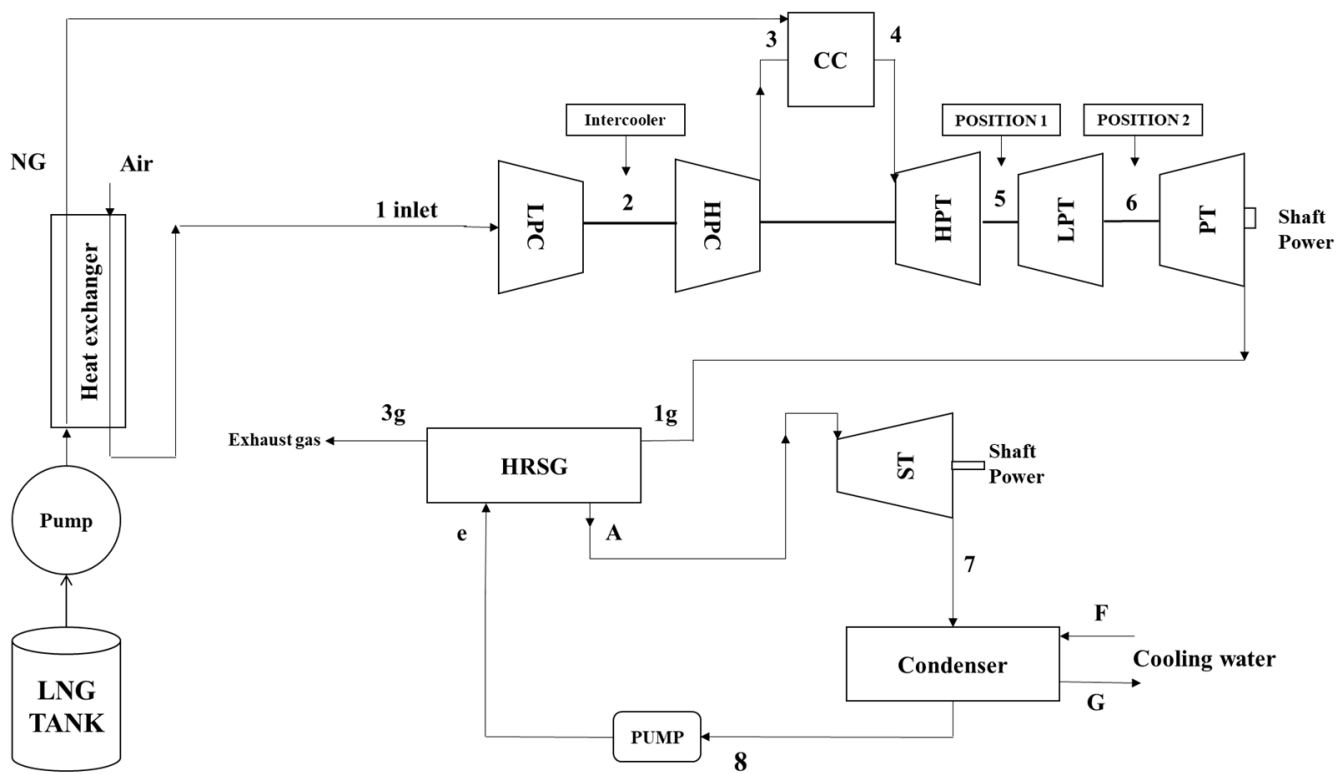

Figure 4. ELNG cycle layout. LNG: liquefied natural gas; HPC: high-pressure compressor; LPC: low-pressure compressor; CC: combustion chamber; S.T.: steam turbine; 1: outlet air mass flow temperature from heat exchanger to low-pressure compressor; NG: the outlet natural gas mass flow from heat exchanger to combustion chamber. 


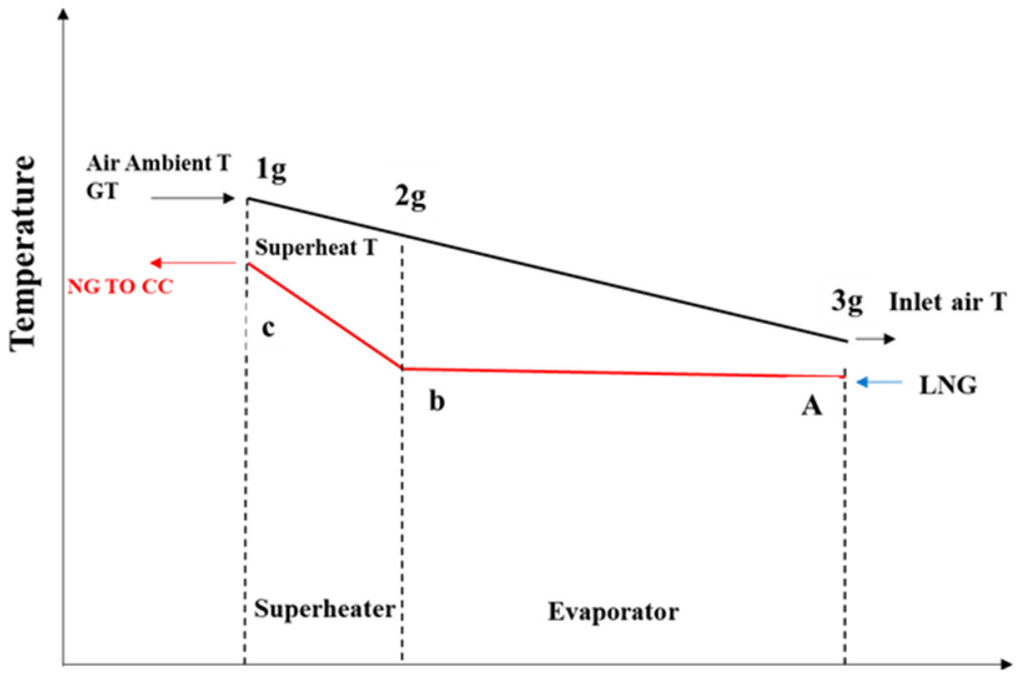

Figure 5. Heat balance in the heat exchanger between LNG and inlet air. 1g: inlet air mass flow temperature to heat exchanger; $2 \mathrm{~g}$ : outlet air mass flow temperature from superheater stagnation to evaporator; $3 \mathrm{~g}$ : outlet air mass flow temperature from heat exchanger to gas turbine; $\mathrm{A}$ : inlet LNG mass flow temperature to heat exchanger; $b$ : outlet LNG mass flow temperature evaporator stagnation to superheater; c: outlet NG mass flow temperature from heat exchanger to combustion chamber gas turbine.

The other feature of LNG is that it permits the use of dry low-NOx combustors [15], which can deliver very low NOx emissions, as demonstrated in land-based gas turbines fuelled by natural gases. In this context, the ELNG cycles are considered with a TET that is $50 \mathrm{~K}$ higher than the other cycles.

\subsection{Estimated Size and Weight of the CCGT}

The total weight related to the CCGT can be determined using the following equation [16,17]:

$$
\mathrm{W}_{\text {total }}=\mathrm{W}_{\mathrm{GT}}+\mathrm{W}_{\mathrm{ST}}+\mathrm{W}_{\mathrm{HRSG}}+\mathrm{W}_{\text {Cond }}+\mathrm{W}_{\text {other }}
$$

where $W_{\mathrm{GT}}$ is the gas turbine weight, $\mathrm{W}_{\mathrm{ST}}$ is the steam turbine weight, $\mathrm{W}_{\mathrm{HRSG}}$ is the HRSG weight, and $\mathrm{W}_{\text {Cond }}$ is the condenser weight.

Since the gas and steam turbines are rotating machines, similar approaches are used to calculate their weights. The same is applied for the HRSG and condenser, as they are heat exchangers. The heat exchanger's surface area is the main factor of its weight [8]. The $\mathrm{W}_{\text {other }}$ is used to estimate the auxiliary equipment weights, such as those for pumps, fan, pipes, and water in the steam turbine cycle, and to monitor and control device weights in the CCGT. A constant percentage $(\mathrm{K})$ range of $3-7 \%$ of the total weight estimated will be included to determine the auxiliary weight.

- Gas and steam turbine weight

General Electric developed a scaling technique to estimate the weight and size of gas and steam turbines based on information from an existing machine [18]. The power $P$ and weight $\mathrm{W}_{\mathrm{GT}}$ of the selected machine can be found in the manufacturer's design. The gas-turbine-specific coefficient for such a machine is:

$$
\mathrm{w}=\mathrm{k} \times \mathrm{P}^{\frac{3}{2}}
$$

The gas-turbine-specific coefficient $(\mathrm{k})$ used for scaling the gas turbine must be calculated. Consequently, the gas and steam turbine weights calculated as functions of power are:

$$
\mathrm{W}_{\mathrm{GT}}=\mathrm{k}_{\mathrm{GT}} \times \mathrm{P}_{\text {gas }}^{\frac{3}{2}}+\mathrm{W}_{\mathrm{GT} \text { stander }}
$$




$$
\mathrm{W}_{\mathrm{ST}}=\mathrm{k}_{\mathrm{ST}} \times \mathrm{P}_{\mathrm{ST}}^{\frac{3}{2}}+\mathrm{W}_{\mathrm{ST} \text { stander }}
$$

where $W_{\mathrm{GT}}$ stander is the weight of the gas turbine from the manufacturer's specifications and $W_{\mathrm{ST}}$ stander is that of the steam turbine from the manufacturer's specifications.

- $\quad$ HRSG and condenser weight

Similarly, for turbine weight estimations, similar investigation methods are used here to calculate the weight of both the condenser and the HRSG. The heat transfer area for the considered HRSG $\left(\mathrm{A}_{\mathrm{HRSG}}\right)$ can be decomposed into the areas of its components, namely the economiser $\left(\mathrm{A}_{\text {Economizier }}\right)$, evaporator $\left(\mathrm{A}_{\text {Evaporator }}\right)$, and superheater $\left(\mathrm{A}_{\text {Superheater }}\right)$.

$$
\begin{array}{r}
\mathrm{A}_{\mathrm{HRSG}}=\mathrm{A}_{\text {Economizier }}+\mathrm{A}_{\text {Evaporator }}+\text { A }_{\text {Superheater }} \\
\mathrm{Q}_{\mathrm{EC}}=\mathrm{U}_{\mathrm{EC}} \mathrm{A}_{\mathrm{EC}} \frac{\left(\mathrm{T}_{2 \mathrm{~g}}-\mathrm{T}_{\mathrm{d}}\right)-\left(\mathrm{T}_{3 \mathrm{~g}}-\mathrm{T}_{\mathrm{e}}\right)}{\operatorname{In}\left(\frac{\mathrm{T}_{2 \mathrm{~g}}-\mathrm{T}_{\mathrm{d}}}{\mathrm{T}_{3 \mathrm{~g}}-\mathrm{T}_{\mathrm{e}}}\right)} \\
\mathrm{Q}_{\mathrm{EV}}=\mathrm{U}_{\mathrm{EV}} \mathrm{A}_{\mathrm{EV}} \frac{\left(\mathrm{T}_{2 \mathrm{~g}^{\prime \prime}}-\mathrm{T}_{\mathrm{b}}\right)-\left(\mathrm{T}_{2 \mathrm{~g}}-\mathrm{T}_{\mathrm{d}}\right)}{\operatorname{In}\left(\frac{\mathrm{T}_{2 \mathrm{~g}^{\prime \prime}}-\mathrm{T}_{\mathrm{b}}}{\mathrm{T}_{2 \mathrm{~g}}-\mathrm{T}_{\mathrm{d}}}\right)} \\
\mathrm{Q}_{\mathrm{SH}}=\mathrm{U}_{\mathrm{SH}} \mathrm{A}_{\mathrm{SH}} \frac{\left(\mathrm{T}_{1 \mathrm{~g}}-\mathrm{T}_{\mathrm{A}}\right)-\left(\mathrm{T}_{2 \mathrm{~g}^{\prime \prime}}-\mathrm{T}_{\mathrm{b}}\right)}{\operatorname{In}\left(\frac{\mathrm{T}_{1 \mathrm{~g}}-\mathrm{T}_{\mathrm{A}}}{\mathrm{T}_{2 \mathrm{~g}^{\prime \prime}}-\mathrm{T}_{\mathrm{b}}}\right)}
\end{array}
$$

where $\mathrm{U}$ is the overall heat transfer coefficient for the heat exchanger and $\mathrm{A}$ is its surface area; $\mathrm{T}_{1 \mathrm{~g}}, \mathrm{~T}_{2 \mathrm{~g}}, \mathrm{~T}_{2 \mathrm{~g}^{\prime \prime}}$, and $\mathrm{T}_{3 \mathrm{~g}}$ are the temperatures in the gas side of the heat exchanger; $\mathrm{T}_{\mathrm{A}}$, $T_{b}, T_{d^{\prime \prime}}, T_{e}$ are the temperatures in the fluid side of the heat exchanger. See Figure 3 for a graphical explanation of the subscript notation used in the temperature calculation.

In Equations (18)-(20), all temperatures of the HRSG are known from the model presented earlier, while the economiser $\left(U_{E C}\right)$, evaporated $\left(U_{E V}\right)$, and superheater $\left(U_{S H}\right)$ heat transfer coefficients have typical values in the ranges of 30-50, 25-65, and 50-90 W/(m2K), respectively [19]. Following the same method, the heat transfer area for the condenser (ACOND) can be calculated as:

$$
\mathrm{Q}_{\mathrm{COND}}=\mathrm{U}_{\mathrm{COND}} \mathrm{A}_{\mathrm{COND}} \frac{\left(\mathrm{T}_{7}-\mathrm{T}_{\mathrm{G}}\right)-\left(\mathrm{T}_{8}-\mathrm{T}_{\mathrm{F}}\right)}{\operatorname{In}\left(\frac{\mathrm{T}_{7}-\mathrm{T}_{\mathrm{G}}}{\mathrm{T}_{8}-\mathrm{T}_{\mathrm{F}}}\right)},
$$

where $T_{7}, T_{8}, T_{G}$, and $T_{F}$ are the temperatures in the condenser, as shown in Figure 2. Again, all temperatures of the condenser are known from the model presented earlier, and the heat transfer coefficient ( $\mathrm{U}_{\mathrm{COND}}$ ) values are in the typical range of $2000-4000 \mathrm{~W} /(\mathrm{m} 2 \mathrm{~K})$ [20]. Importantly, the heat transfer coefficient values $\left(\mathrm{U}_{\mathrm{EC}}, \mathrm{U}_{\mathrm{EV}}, \mathrm{U}_{\mathrm{SH}}\right.$, and $\left.\mathrm{U}_{\mathrm{COND}}\right)$ will be assumed constant. The following expressions will be used for the HRSG and condenser weight:

$$
\begin{gathered}
\mathrm{w}_{\mathrm{HRSG}}=\mathrm{K}_{\mathrm{HRSG}} \times \mathrm{A}_{\mathrm{HRSG}}+\mathrm{P}_{\mathrm{HRSG}}, \\
\mathrm{w}_{\mathrm{COND}}=\mathrm{K}_{\mathrm{COND}} \times \mathrm{A}_{\mathrm{COND}}+\mathrm{P}_{\mathrm{COND}} .
\end{gathered}
$$

\subsection{Environmental Model}

This model will assess the emissions from all CCGT cycles fuelled by the LNG and MDO and from a two-stroke diesel engine fuelled by MDO. The assessment will be based on the emission factors and fuel consumption of the propulsion system. This study will examine $\mathrm{NOx}$ and $\mathrm{CO}_{2}$ emissions.

- $\quad$ Nitrogen Oxides NOx: 
NOx is produced as a by-product of combustion in engines where nitrogen and oxygen react in the air. Their production depends on the temperature and pressure of the combustion [21].

- Carbon dioxide $\mathrm{CO}_{2}$ :

When energy is produced by consuming oxygen, $\mathrm{CO}_{2}$ is produced [22]. However, excess $\mathrm{CO}_{2}$ traps heat in the atmosphere, making the earth warmer [23]. The average global temperature increase for this century is estimated to be between 0.5 and $4.0{ }^{\circ} \mathrm{C}$ [24].

Two different procedures can be used to estimate emissions: fuel consumption and engine power [25]. The emissions are estimated from fuel consumption here, which can be expressed as:

$$
\mathrm{E}=\sum\left(\mathrm{FC}_{\mathrm{j}, \mathrm{m}, \mathrm{p}} \times \mathrm{EF}_{\mathrm{i}, \mathrm{j}, \mathrm{m}}\right),
$$

where E represents the emissions (tonnes/hr), F.C. is the fuel consumption (tonnes/hr), E.F. is the emission factor ( $\mathrm{kg} /$ tonne), $\mathrm{i}$ is the pollutant, $\mathrm{j}$ is the engine type (slow-speed diesel engine, gas turbine, and steam turbine), and $\mathrm{m}$ is the fuel type (bunker fuel oil, $\mathrm{MDO} / \mathrm{marine}$ gas oil, and gasoline).

\subsection{Assumptions, Simulation, and Validation}

The influence of the parameters, namely the cycle compression ratio, TET, ambient temperature, and fuel type (LNG and MDO), on the performance of CCGT cycles is discussed in this section. The effects on the power output and efficiency were evaluated using the Turbomatch and MATLAB software. The simulation results for G.T. obtained via the D.P. simple cycle matching for RB211-6762 are presented in Table 1.

Table 1. Turbomatch output design point (D.P.) parameters of the simple-cycle gas turbine.

\begin{tabular}{cccc}
\hline Parameter & Simulated Value & Actual Value & Deviation \% \\
\hline Thermal Efficiency $(\%)$ & 38.1 & 38.8 & -0.494 \\
Exhaust Gas Temperature $\left({ }^{\circ} \mathrm{C}\right)$ & 492.83 & 492 & 0.586 \\
Exhaust Mass Flow $(\mathrm{kg} / \mathrm{s})$ & 96.066 & 96 & 0.046 \\
\hline
\end{tabular}

However, the inlet steam temperature depends on the material development. Regarding parts design for superheaters, piping, and valves exposed to high steam temperatures, there is a steam temperature limit based on the material strength, structural design, and cost. Currently, the highest inlet steam temperature range is between $566{ }^{\circ} \mathrm{C}$ and $620{ }^{\circ} \mathrm{C}$ [4]. With newer technology, it has been assumed that the maximum temperature can reach $600{ }^{\circ} \mathrm{C}$. The assumptions for the three G.T. cycles, HRSG, and steam turbine are presented in Tables 2 and 3, respectively.

Table 2. Assumed parameters of the G.T. cycles.

\begin{tabular}{cc}
\hline Parameter & Value \\
\hline Ambient Conditions & $15^{\circ} \mathrm{C}=288 \mathrm{~K}$, \\
$1 \mathrm{~atm}=101 \mathrm{kPa}$ \\
Compressor Isentropic Efficiency (\%) & 87 \\
Intercooler Efficiency (\%) & 99 \\
Combustor Efficiency (\%) $=$ HPC Pressure Ratio for Simple-Cycle Variable & LPC = 4.6368/HPC = 4.6368 \\
Turbine Isentropic Efficiency (\%) & 99 \\
Power Turbine Isentropic Efficiency (\%) & 88.0 \\
Mass Flow (kg/s) & 106 \\
Combustor Pressure Loss (\%) & 5.0 \\
Bleed Air for Turbine Cooling (\% of Core Mass Flow) & 10.0 \\
Intake/Nozzle Pressure Loss (\%) & 0.0 \\
TET: turbine entry temperature (K) Variable & 1600 \\
Exhaust Pressure Loss $(\%)$ & 2 \\
Intercooler Pressure Loss (\%) & 2 \\
Humidity (\%) & 60 \\
\hline
\end{tabular}


Table 3. Steam model with single HRSG assumption.

\begin{tabular}{cc}
\hline Parameter & Value \\
\hline Steam Turbine Isentropic Efficiency (\%) & 88 \\
Output power (MW) & Up to 20 \\
Approach point (C) & 7.5 \\
Pinch point (C) & 20 \\
Steam turbine efficiency & 88.0 \\
Superheated pressure (bar) & 60 \\
Condenser pressure (bar) & 0.06 \\
Pump pressure (bar) & 3 \\
Steam turbine Isentropic Efficiency (\%) & 88 \\
\hline
\end{tabular}

\section{Results}

\subsection{Technical D.P. and Off-Design Point (O.D.) Results for All CCGT Cycles} 3.1.1. D.P. of CCGT Cycles

- $\quad$ Combined cycle (CCGT) with a simple-cycle gas turbine

Single-shaft gas turbines are acceptable if coupled to a constant-speed propeller with controllable pitch. The G.T. and propeller can run at a constant speed, and the control system carefully synchronises the fuel flow with the power requirement as the propeller pitch is changed. Given that the application is a container ship expected to sail for very long periods at nearly constant power, this scheme is considered reasonable. Furthermore, if a separate and independent power turbine was chosen, the fuel consumption details (this is a key objective of the paper) presented here would not change.

The optimum pressure ratio for a gas turbine in a combined cycle application is significantly lower than that required to achieve peak thermal efficiency using a simplecycle gas turbine. The air leaves the compressor at a higher temperature when an increased pressure ratio occurs. Therefore, achieving the desired turbine entry temperature requires less fuel [26]. Therefore, the compressor and output power work will increase by increasing the pressure ratio then decreasing the exhaust gas temperature. This will result in lower steam production from HRSG, thereby lowering the outputs of the steam cycle. Figure 6 shows the variations in the compression ratio from 21.5 to 60 and the effects on the overall thermal efficiency for the simple-cycle CCGT at the D.P. with different fuels (TET = 1600). The overall thermal efficiency decreases for the CCGT because an increase in the compressor ratio reduces the exhaust temperature of G.T., which decreases the HRSG efficiency. The efficiency of the HRSG increases with an increasing exhaust G.T. temperature. Furthermore, there is a slight difference between LNG and MDO fuels in their overall thermal efficiency.

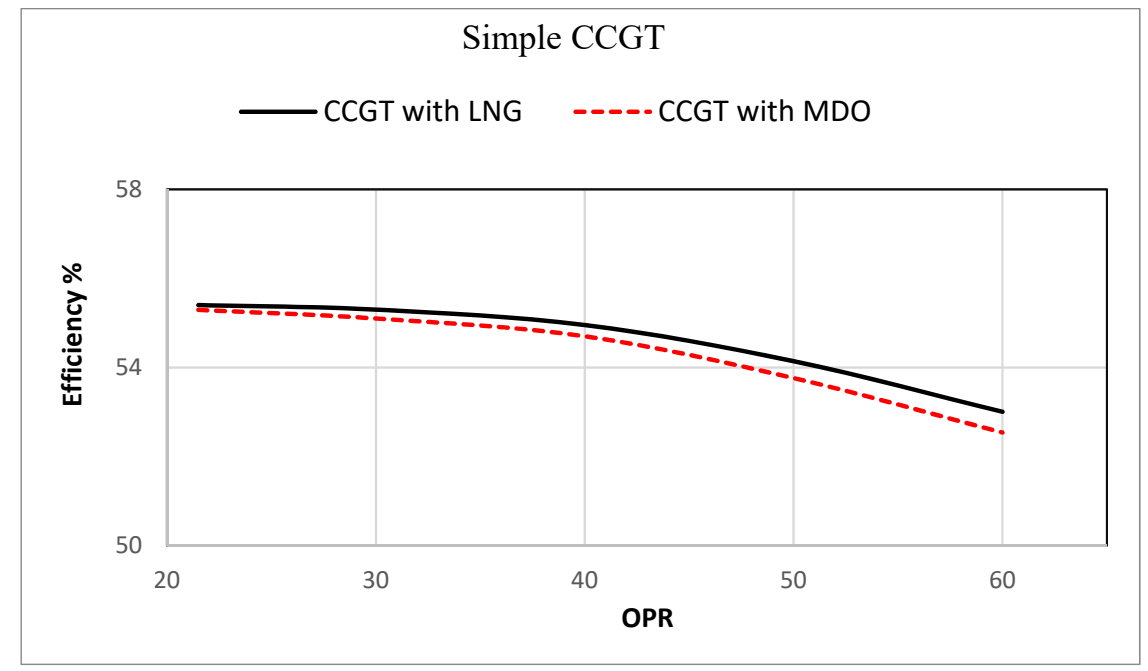

Figure 6. Effects of the compression ratio on the overall thermal efficiency. MDO: marine diesel oil; OPR: overall pressure ratio. 
- $\quad$ Combined cycle (CCGT) with a reheat cycle gas turbine

For the reheat cycle, the best location must be selected for the reheater between the HPT and LPT or the LPT and P.T. in the G.T. at the D.P., with an overall pressure ratio (OPR) that allows the optimal overall efficiency and an exhaust temperature that influences the CCGT. Figure 7 shows the effects of the OPR of the low-pressure compressor (LPC) on the reheat cycle gas turbine. The efficiency increases for OPR when the reheat location is between the HPT and LPT and decreases when the reheat location is between the LPT and P.T. Since this study aimed to find the optimal location for the reheater with overall efficiency at the D.P., we selected the reheat location between the HPT and LPT with a different OPR to obtain the optimal efficiency for the exhaust temperature that increases the efficiency of the CCGT.

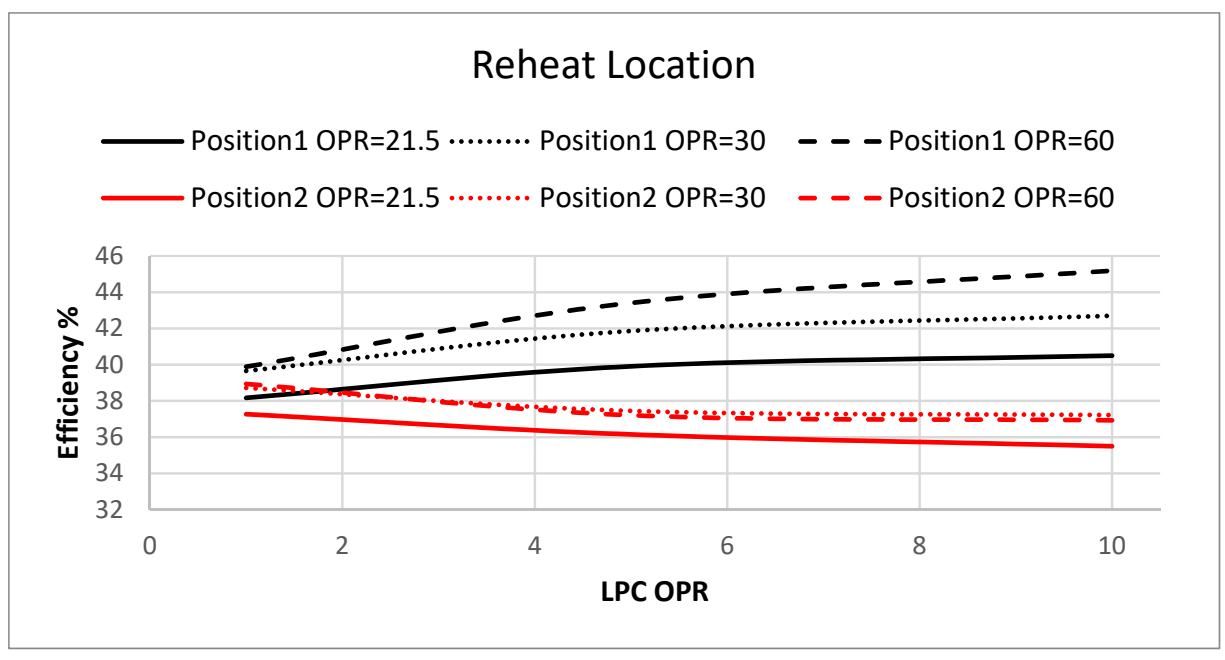

Figure 7. Effects of the compression ratio with different LPCs in the reheat cycle.

Figure $8 \mathrm{~A}, \mathrm{~B}$ shows the variations in the compression ratio from 21.5 to 90 and the effects on the overall thermal efficiency of the reheat CCGT at the D.P. The overall thermal efficiency decreases as the LPC compression ratio's effect on the CCGT increases. This is because an increase in the LPC compression ratio reduces the exhaust temperature of the G.T., which decreases the HRSG efficiency. The range of life materials is from LPC 8 to LPC 10 (as the highest inlet steam temperature currently applied is between $566{ }^{\circ} \mathrm{C}$ and $620^{\circ} \mathrm{C}$ [27] of the steam turbine, with the EGT from the G.T. recording being below $600{ }^{\circ} \mathrm{C}$.) The difference in efficiency from 40 to 90 OPR is less than one per cent; from an economic perspective, a small compression ratio is better. Thus, an OPR of 40 was selected in this study.

- $\quad$ Combined cycle (CCGT) with an I/R gas turbine

For the I/R turbine, we select the best location for the intercooler as being between the G.T. at D.P. with OPR to obtain the optimal overall efficiency and exhaust temperature, which influence the CCGT. Figure 9A,B shows the effects of the LPC OPR on the I/R CCGT cycle. The overall thermal efficiency increases as the LPC compression ratio and CCGT increase and decrease, respectively. This is because an increase in the LPC compression ratio reduces the exhaust temperature of the G.T., which decreases the HRSG efficiency. The material life range is from LPC 3.5 to LPC 10, where the EGT from the G.T. can be tolerated by the steam turbine. The difference in efficiency from 60 to 90 OPR is less than one per cent at the LPC 4 compression ratio; from an economic perspective, a small compression ratio is better. Thus, an OPR of 60 was selected in this study. 

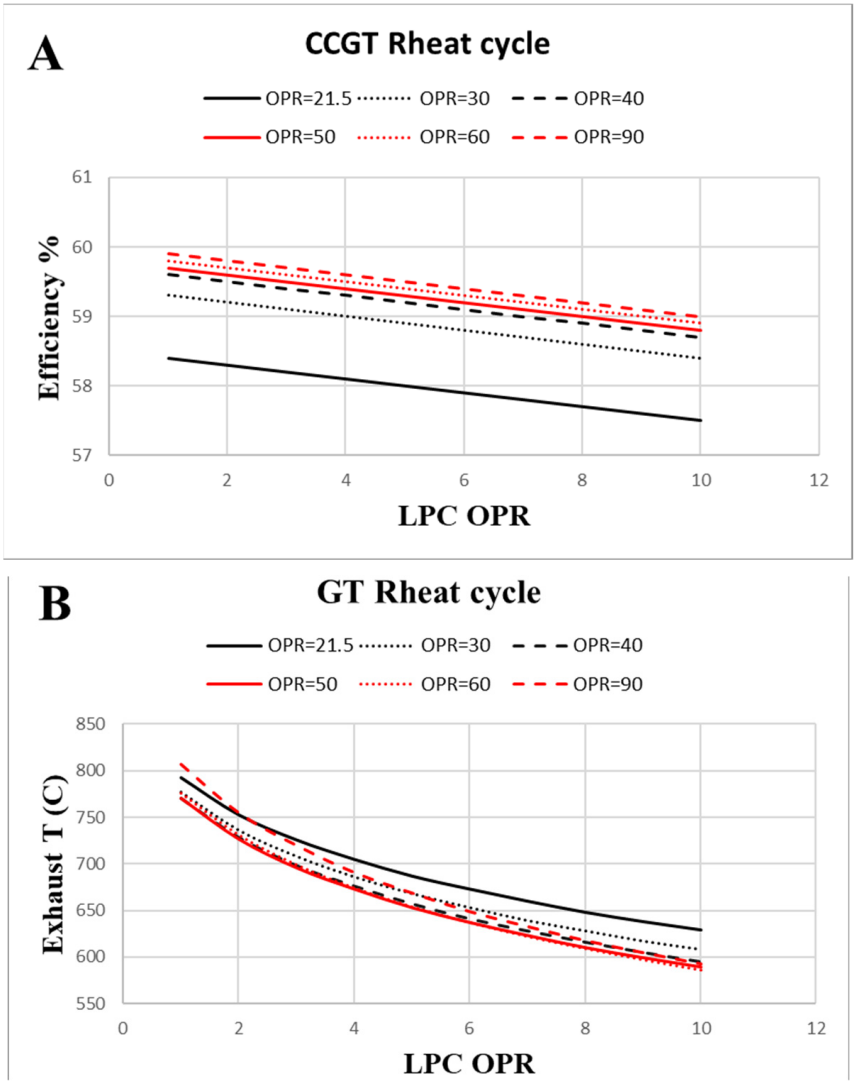

Figure 8. (A) Effects of the compression ratio with changing LPCs in the reheat CCGT cycle. (B) Effects of the compression ratio with changing LPCs in the reheat GT cycle.
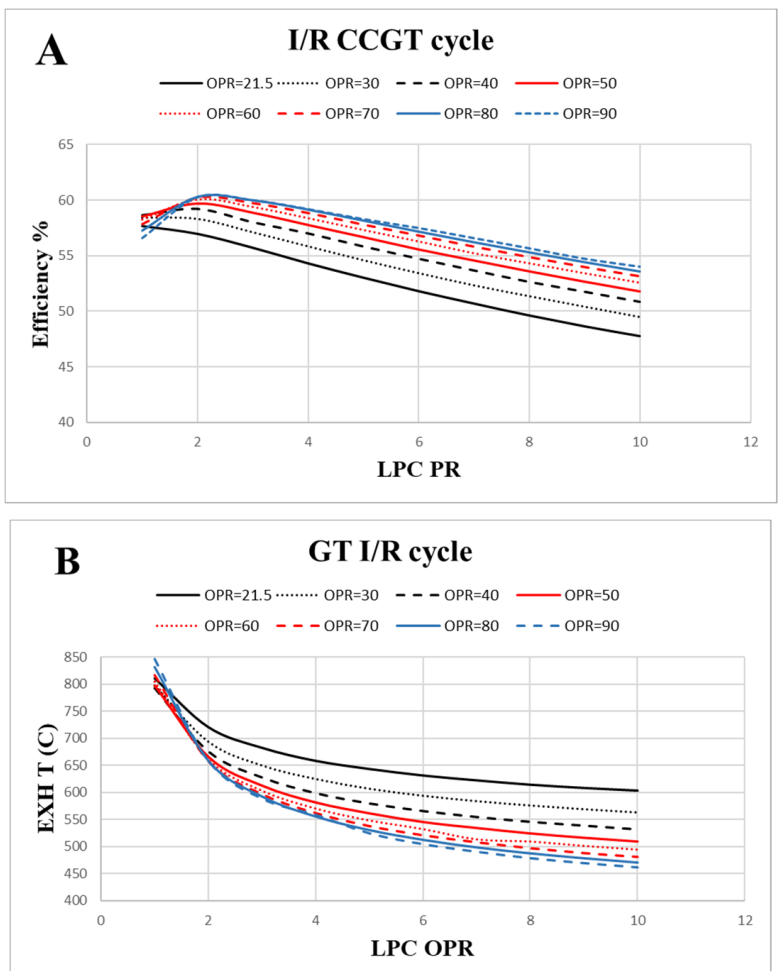

Figure 9. (A) Effects of the compression ratio with changing LPC in the I/R CCGT cycle. (B) Effects of the compression ratio with changing LPC in the I/R GT cycle. 
For the D.P. of simple, reheat, and I/R systems, the reheat and I/R cycles compete for efficiency. Thus, we selected those two cycles and examined them at the O.D.

\subsubsection{O.D. of CCGT Cycles}

\section{- $\quad$ Effect of TET on CCGT}

Figure 10 shows the effects of TET values ranging from 1500 to $1800 \mathrm{~K}$ for the CCGT at O.D. in terms of efficiency with different fuels. With increasing TET values, the CCGT efficiency increases and then decreases. The efficiency of the CCGT with TET decreased due to the constant EGT when it was above $873 \mathrm{~K}$. The difference between TET $=1600 \mathrm{~K}$ and TET $=1800 \mathrm{~K}$ is less than $2 \%$ in terms of efficiency; thus, TET $=1600 \mathrm{~K}$ was selected for the environmental aspect. I/R CCGT cycle was more efficient than the reheat cycle.

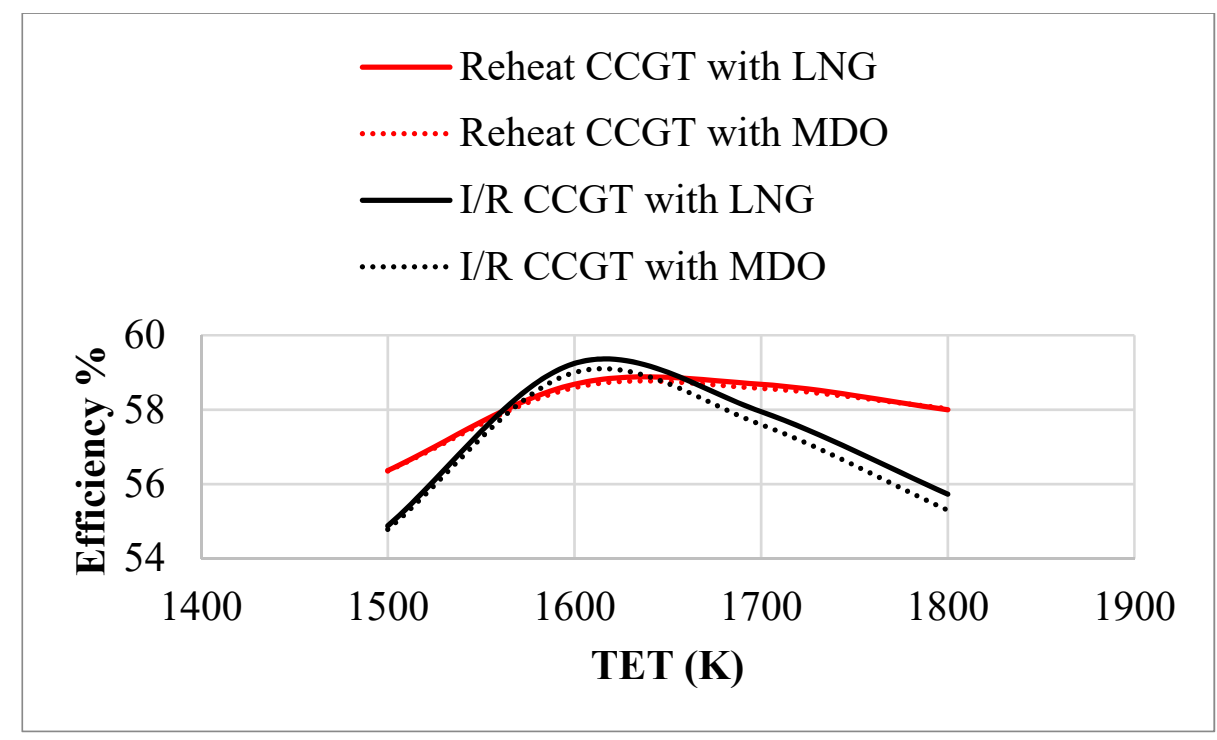

Figure 10. Effect of the TET on the overall thermal efficiency.

- $\quad$ Effect of ambient temperature on CCGT

The air density changes with the change in ambient temperature. An increased ambient temperature decreases the density of the inlet air, thereby reducing the mass flow through the turbine, which decreases the power output. Furthermore, for a given TET, it reduces the temperature ratio and the pressure ratio of the gas turbine cycle, thereby ultimately reducing the specific power and efficiency. Table 4 shows the effect of the ELNG CCGT cycle on the fuel-to-air ratio and the ambient temperature. This table results from an iterative calculation, where TET is constant and FAR and compressor inlet temperatures are varied until they match.

Table 4. Effects of the ELNG cycle on the fuel-to-air ratio and the ambient temperature.

\begin{tabular}{ccc}
\hline Ambient Temperature & Reduction in Ambient Temperature & FAR \\
\hline 288 & 269.5 & 0.03211 \\
298 & 279.5 & 0.03223 \\
308 & 289.5 & 0.03245 \\
318 & 299.5 & 0.03284
\end{tabular}

Figure 11 shows the effects of ambient temperature values from -20 to $45{ }^{\circ} \mathrm{C}$ on the efficiency of the reheat, I/R, and ELNG CCGT systems at the O.D. With increasing ambient temperature, the efficiency of the CCGT decreases; ELNG cycles show higher efficiency than the other cycles. 


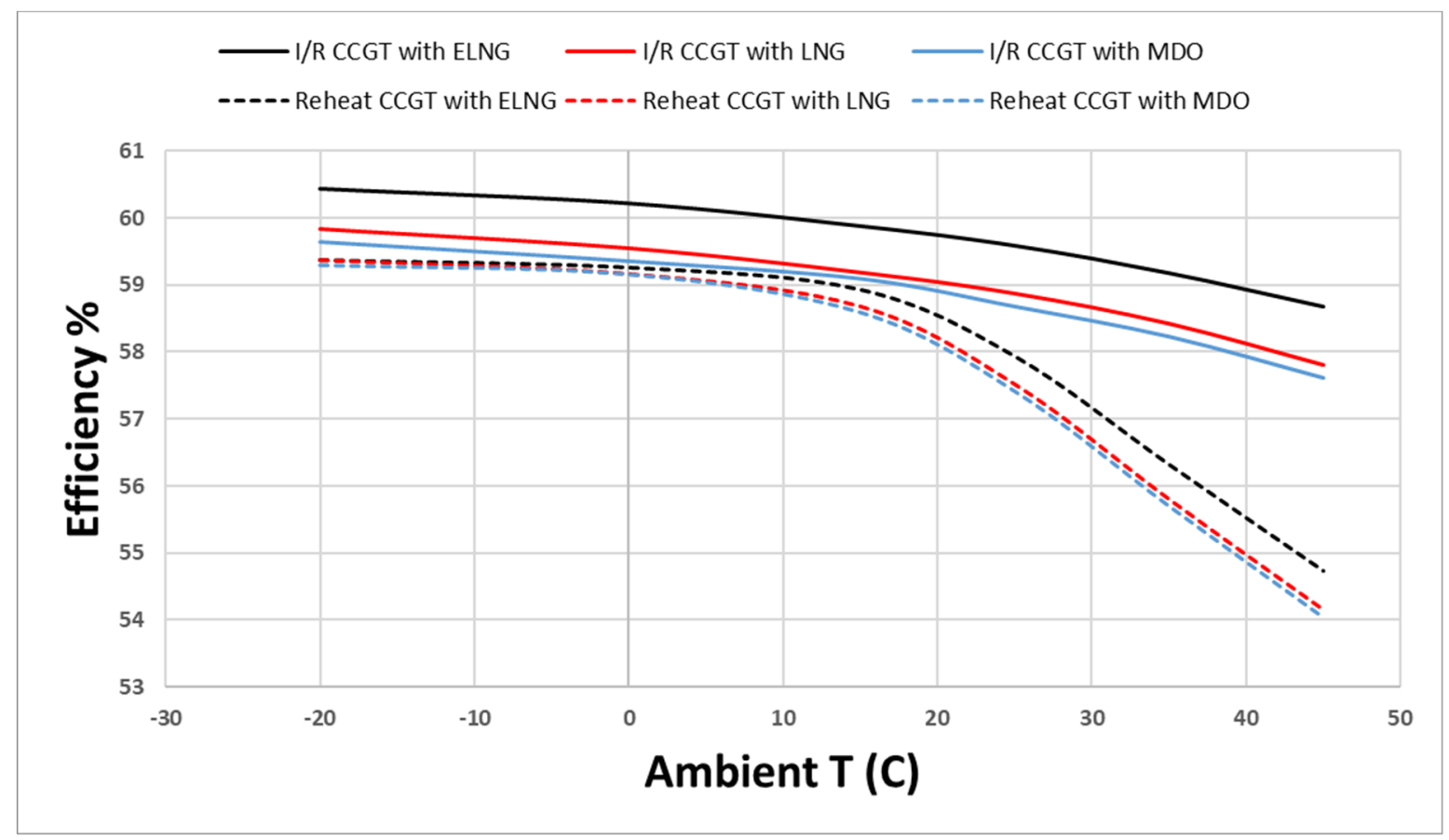

Figure 11. Effects of the ambient temperature on the overall thermal efficiency.

\subsection{Environmental Results}

As discussed earlier, for this study, only $\mathrm{NOx}$ and $\mathrm{CO}_{2}$ emissions were considered. It was assumed that the CCGT burns LNG and MDO, and the two-stroke diesel engine burns MDO. It was also assumed that $\mathrm{NO}_{x}$ and $\mathrm{CO}_{2}$ were used for CCGT and two-stroke diesel engine emission factors in $\mathrm{g} / \mathrm{kWh}$ regarding the engine or fuel type found in [28-34], as shown in Table 5.

Table 5. Emissions factor for the CCGT and two-stroke diesel engines.

\begin{tabular}{|c|c|c|}
\hline Emission Factors (g/kWh) & NOx (g/kWh) & $\mathrm{CO}_{2}(\mathrm{~g} / \mathrm{kWh})$ \\
\hline Diesel engine with MDO & 9 & 588 \\
\hline CCGT with MDO & 5.7 & 524 \\
\hline CCGT with LNG & 3.05 & 522 \\
\hline CCGT with ELNG & 1.17 & 412 \\
\hline
\end{tabular}

Figure 12 shows the effect of TET with NOx emission on all CCGT cycles; increasing the TET increases the NOX emission. Notably, the I/R and simple cycle perform better than the reheat cycle owing to the higher fuel flow in the reheat cycle.

Figure 13 shows the effect of the TET on the $\mathrm{CO}_{2}$ emissions for all CCGT cycles; increasing the TET decreases the $\mathrm{CO}_{2}$ emissions.

Figures 14 and 15 show all of the CCGT cycles and diesel two-stroke engine emissions. The CCGT cycles are fewer than the two-stroke diesel engine cycles for both $\mathrm{NO}_{\mathrm{X}}$ and $\mathrm{CO}_{2}$. 


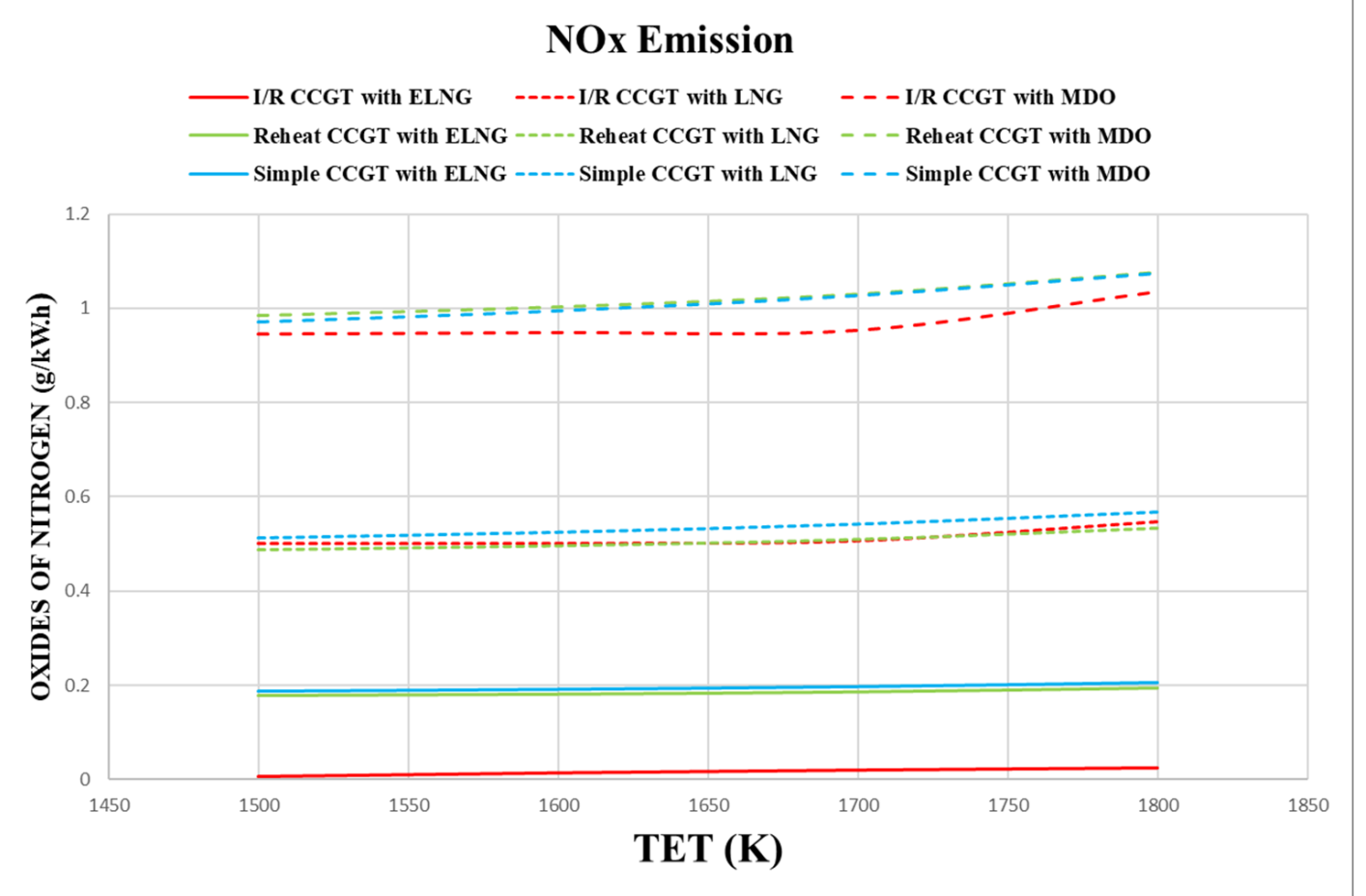

Figure 12. Effects of the TET on the NOx.

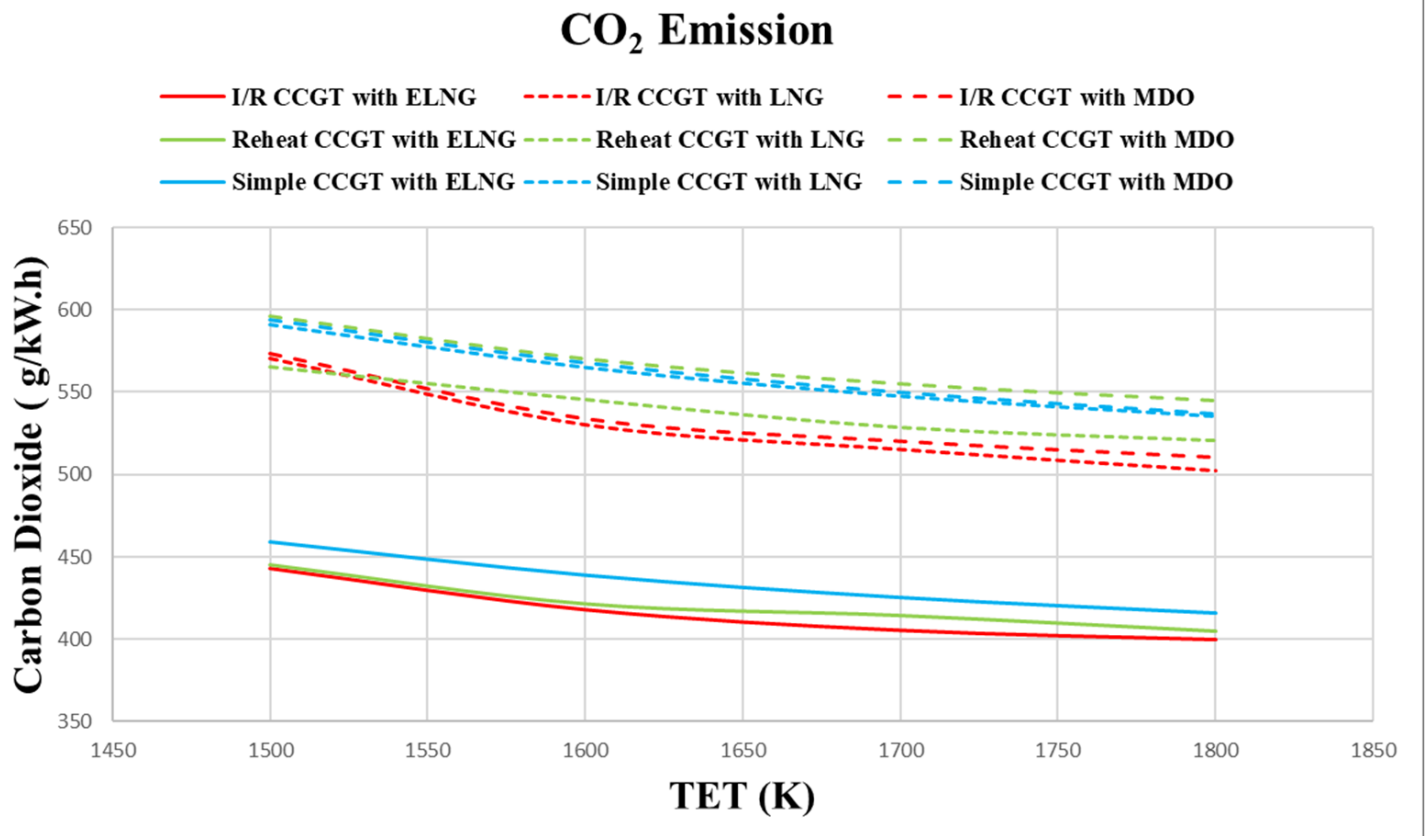

Figure 13. Effects of the TET on the $\mathrm{CO}_{2}$ emissions. 


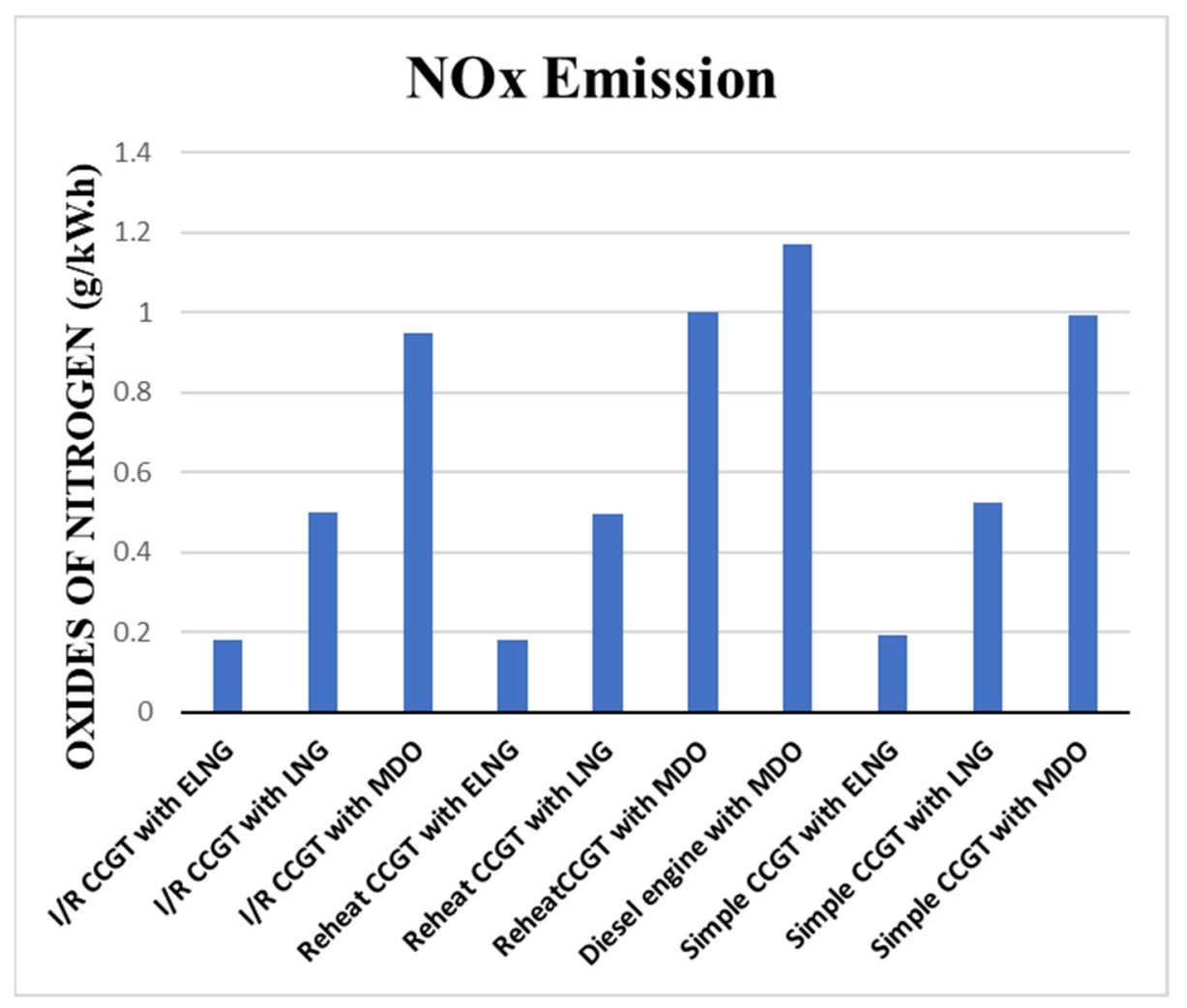

Figure 14. NOx emissions from all propulsion systems.

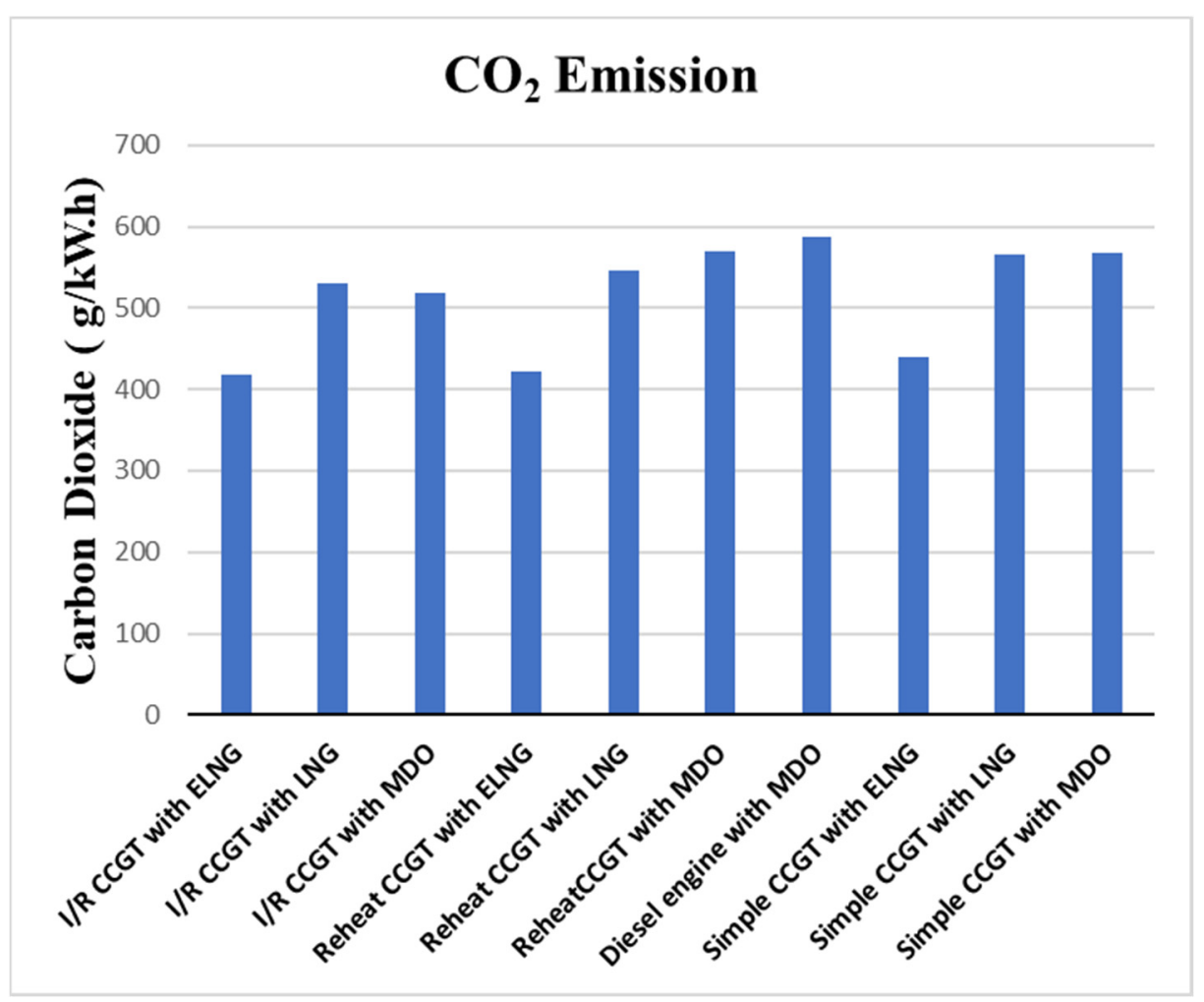

Figure 15. $\mathrm{CO}_{2}$ emissions from all propulsion systems. 


\subsection{Engine Size and Weight}

The data presented in Tables 6 and 7 show the power, weight, and $k_{\mathrm{GT}}$ values for a number of commercially available gas turbines and steam turbines. The data indicate that as the weight increases, the value for $\mathrm{k}_{\mathrm{GT}}$ decreases.

Table 6. Commercially available gas turbine weights.

\begin{tabular}{ccccc}
\hline $\begin{array}{c}\text { Gas Turbine } \\
\text { Manufacturer \& } \\
\text { Model Number }\end{array}$ & $\begin{array}{c}\text { Power } \\
\text { (MW) }\end{array}$ & $\begin{array}{c}\text { Weight } \\
\text { (tonne) }\end{array}$ & $\mathbf{k}_{\mathrm{GT}} \frac{\text { tonne }}{\mathbf{W}^{3 / 2}}$ & $\begin{array}{c}\text { Gas Turbine } \\
\text { Manufacturer \& } \\
\text { Model Number }\end{array}$ \\
\hline $\begin{array}{c}\text { MT7 } \\
\text { RB211-6762 }\end{array}$ & 4.6 & 0.45 & 0.04561 & MT7 \\
MT30 & 30.387 & 22.680 & 0.13545 & RB211-6762 \\
MT30 \\
\hline
\end{tabular}

Table 7. Commercially available steam turbine weights.

\begin{tabular}{ccccc}
\hline $\begin{array}{c}\text { Steam Turbine } \\
\text { Manufacturer \& } \\
\text { Model Number }\end{array}$ & $\begin{array}{c}\text { Power } \\
\text { (MW) }\end{array}$ & $\begin{array}{c}\text { Weight } \\
\text { (tonne) }\end{array}$ & $\mathbf{k}_{\mathrm{GT}} \frac{\text { tonne }}{\mathbf{W}^{3 / 2}}$ & $\begin{array}{c}\text { Steam Turbine } \\
\text { Manufacturer \& } \\
\text { Model Number }\end{array}$ \\
\hline $\begin{array}{c}\text { ELLIOT MYR } \\
\text { (8-stage) }\end{array}$ & 7.5 & 7.71 & 0.37488 & $\begin{array}{c}\text { ELLIOT MYR } \\
\text { (8-stage) }\end{array}$ \\
$\begin{array}{c}\text { ELLIOT MYR 2SQV6 } \\
\text { Siemens SST 300 }\end{array}$ & 11 & 11.5 & 0.3152 & $\begin{array}{c}\text { ELLIOT MYR 2SQV6 } \\
\text { Siemens SST 300 }\end{array}$ \\
\hline
\end{tabular}

As mentioned before, the CCGT is an alternative propulsion system to a 2-stroke diesel engine for a large container ship, which has higher efficiency and uses better quality fuel but has a more complex configuration. However, because of the abovementioned emission regulations, it is reasonable to presume that cleaner fuel for diesel engines will be implemented, and this condition could favour the choice of CCGT solution for large container ships, as they also consider fuel costs $[35,36]$. The main data considered for the propulsion of the CSCL GLOBE 19,000 twenty-foot equivalent unit container ship [37] are summarised in Table 8.

Table 8. Main data considered for the CSCL Globe 19,000 twenty-foot equivalent unit container ship.

\begin{tabular}{cc}
\hline Length Overall & $399.67 \mathrm{~m}$ \\
Breadth & $58.73 \mathrm{~m}$ \\
Depth & $30.5 \mathrm{~m}$ \\
Draught & $16 \mathrm{~m}$ \\
Engine Power & $56 \mathrm{MW}$ \\
Engine model & $11 \mathrm{k} 98 \mathrm{ME} 7$ \\
Gross Tonnage & $187,541 \mathrm{t}$ \\
Net Tonnage & $86,434 \mathrm{t}$ \\
Speed & $23 \mathrm{knots}$ \\
\hline
\end{tabular}

A nine-cylinder, two-stroke diesel engine with a slow speed (MAN B\&W K98ME7.1TII) and developing power of $56.070 \mathrm{Mw}$ at $97 \mathrm{rpm}$ is the prime mover in the CSCL Globe container ship, without reduction gear [38]. Table 9 clearly shows that the two-stroke diesel engine is much larger and heavier than the CCGT. A further comparison in terms of the weight of the overall propulsion system is presented. 
Table 9. Data for the considered prime movers.

\begin{tabular}{ccccc}
\hline Engine Data & K98ME7.1-TII & Gas Turbine & Steam Turbine & HRSG \\
\hline Length $(\mathrm{m})$ & 27.36 & 4.57 & 12 & 6.33 \\
Height $(\mathrm{m})$ & 19.35 & 2.41 & 5 & 11.7 \\
Breadth $(\mathrm{m})$ & 11.36 & 2.21 & 4 & 6.16 \\
Weight $(\mathrm{t})$ & 2500 & 40.8 & 26 & 197.7 \\
Power $(\mathrm{mw})$ & 56 & 45 & 20 & \\
\hline
\end{tabular}

The overall propulsion plant weights are presented in Table 10. The reduction gear, HRSG, condenser, and pump weights were selected as per a previous study [9]. The second combustor weight was calculated by comparing the first combustor density with the second one from the mass flow rate (assuming constant speed), as the density is proportional to the volume. The heat exchanger and intercooler weights were taken from the HRSG weight and mass flow and scaled with the mass flow in the heat exchanger and intercooler to obtain their weights. From Table 10, it is clear that the CCGT has a greater number of components (gas turbine, steam turbine, HRSG, condenser, and reduction gear). The CCGT propulsion system, with all components of the cycles, is approximately 1687 tonnes lighter than the original diesel engine propulsion system. Regarding the size of the CCGT and how it will fit in a container ship, [2,9] showed clearly that the CCGT is smaller than a two-stroke diesel engine in a large container ship. The reduction in size in the engine room and reduced machinery weights for the CCGT solution allow an increased load capacity for the ship.

Table 10. Comparison of weights.

\begin{tabular}{cccccc}
\hline Component & $\begin{array}{c}\text { Diesel } \\
\text { Engine }\end{array}$ & $\begin{array}{c}\text { Simple } \\
\text { CCGT }\end{array}$ & $\begin{array}{c}\text { Reheat } \\
\text { CCGT }\end{array}$ & $\begin{array}{c}\text { I/R } \\
\text { CCGT }\end{array}$ & $\begin{array}{c}\text { ELNG } \\
\text { CCGT }\end{array}$ \\
\hline Diesel engine $(\mathrm{t})$ & 2500 & - & - & - & - \\
Gas turbine $(\mathrm{t})$ & - & 40.8 & 40.8 & 40.8 & 40.8 \\
Steam turbine $(\mathrm{t})$ & - & 26 & 26 & 26 & 26 \\
HRSG $(\mathrm{t})$ & - & 197.7 & 197.7 & 197.7 & 197.7 \\
Condenser $(\mathrm{t})$ & - & 62.7 & 62.7 & 62.7 & 62.7 \\
Pump $(\mathrm{t})$ & - & 13.8 & 13.8 & 13.8 & 13.8 \\
Reduction gear $(\mathrm{t})$ & - & 278 & 278 & 278 & 278 \\
Second combustor $(\mathrm{t})$ & - & - & 5.9 & 5.9 & 5.9 \\
Intercooler $(\mathrm{t})$ & - & - & - & 67.38 & 67.38 \\
Second Pump $(\mathrm{t})$ & - & - & - & - & 8.4 \\
Heat exchanger $(\mathrm{t})$ & - & - & - & - & 111.67 \\
Total weight $(\mathrm{t})$ & 2500 & 619 & 624.9 & 692.28 & 812.39 \\
\hline
\end{tabular}

\section{Conclusions}

This study aimed to present CCGT systems as a good alternative to two-stroke diesel engine propulsion systems in large container ships because of their performance, emissions, size, and weight. In terms of performance, in the reheat cycle, the efficiency increased with OPR when the reheat location was between HPT and LPT and decreased when the reheat location was between LPT and P.T. In the reheat-intercooler cycle, the overall thermal efficiency increased as the LPC compression ratio and CCGT increased and decreased, respectively. This was because an increase in the LPC compression ratio reduced the exhaust temperature of the G.T., which decreased the HRSG efficiency. With an increasing TET, the CCGT efficiency increased and then decreased. Its efficiency decreased when the TET was constant because the EGT was above $873 \mathrm{~K}$. The difference between TET $=1600 \mathrm{~K}$ and TET $=1800 \mathrm{~K}$ is less than $2 \%$ in terms of efficiency. With an increasing ambient temperature, the efficiency of CCGT decreased. The CCGT was more efficient in burning LNG than MDO. ELNG cycles showed better results in terms of efficiency. For the NOx emission of all CCGT cycles, an increasing TET increased the NOx emission. Furthermore, increasing the 
TET decreased the $\mathrm{CO}_{2}$ emissions, which made the TET more efficient. Thus, the $\mathrm{NO}_{\mathrm{X}}$ and $\mathrm{CO}_{2}$ emissions in CCGT cycles were lower than those in the two-stroke diesel engine. The CCGT propulsion system, with all of the components of all cycles, was approximately 1687 tonnes lighter than the original diesel engine propulsion system in the large container ship. The best alternative propulsion systems for the large container ship propulsion system with comprehensive consideration of the thermal and environmental performance was the I/R ELNG CCGT system, while in terms of weight this was the simple CCGT system.

Author Contributions: A.M.T.A.: Conceptualization, Data curation, Formal analysis, Funding acquisition, Investigation, Methodology, Project. administration, Resources, Software. S.S.: Supervision. P.P.: Supervision. All authors have read and agreed to the published version of the manuscript.

Funding: This research received no external funding.

Institutional Review Board Statement: Not applicable.

Informed Consent Statement: Not applicable.

Data Availability Statement: Not applicable.

Acknowledgments: The authors are grateful toward the Government of the State of Kuwait and the Public Authority for Applied Education and Training (PAAET) for the provisions and the financial support.

Conflicts of Interest: The authors declare that there is no conflict of interest.

\section{References}

1. Alrashed, M.; Nikolaidis, T.; Pilidis, P.; Alrashed, W.; Jafari, S. Economic and environmental viability assessment of NASA's turboelectric distribution propulsion. Energy Rep. 2020, 6, 1685-1695. [CrossRef]

2. Altosole, M.; Benvenuto, G.; Campora, U.; Laviola, M.; Trucco, A. Waste heat recovery from marine gas turbines and diesel engines. Energies 2017, 10, 718. [CrossRef]

3. Wiggins, E.G. COGAS propulsion for LNG ships. J. Mar. Sci. Appl. 2011, 10, 175-183. [CrossRef]

4. Bengtsson, S.; Fridell, E.; Andersson, K. Environmental assessment of two pathways towards the use of biofuels in shipping. Energy Policy 2012, 44, 451-463. [CrossRef]

5. Benvenuto, G.; Bertetta, D.; Carollo, F.; Campora, U. COGAS plant as possible future alternative to the diesel engine for the propulsion of large ships. Sustain. Marit. Transp. Exploit. SEA Res. 2011, 2, 603-614. [CrossRef]

6. Benvenuto, G.; Laviola, M.; Campora, U. Assessment of steam cycle layouts for COGAS ship propulsion systems. In Proceedings of the MARTECH (February): 2nd International Conference on Maritime Technology and Engineering, Lisbon, Portugal, 15-17 October 2014; pp. 743-754. [CrossRef]

7. Brandt, D.G.E. Gas Turbine Philosophy G.E. Power Generation; GE Industrial \& Power Systems: Schenectady, NY, USA, 1994.

8. Brynolf, S.; Fridell, E.; Andersson, K. Environmental assessment of marine fuels: Liquefied natural gas, liquefied biogas, methanol and bio-methanol. J. Clean. Prod. 2014, 74, 86-95. [CrossRef]

9. Coleman, M.J. Florida State University libraries ship weight reduction and efficiency enhancement through combined power cycles. Energy 2015, 93, 521-533. [CrossRef]

10. Hallegatte, E.K.L.; Kram, S.; Arnell, T.; Carter, N.W.; Edmonds, T.R.; Kriegler, J.; Mathur, E.; O’Neill, R.; Riahi, B.C.; Winkler, K.; et al. A new scenario framework for climate change research: Background, process, and future directions. Clim. Change 2014, 122, 363-372. [CrossRef]

11. RGas Turbine engines RB211-Rolls Royce-PDF Catalogs Technical Documentation Brochure. Available online: https://pdf. directindustry.com/pdf/rolls-royce/gas-turbine-engines-rb211/22649-86918.html (accessed on 20 November 2021).

12. Emmanuel-Douglas, I. Performance evaluation of combined cycles for cruise ship applications. Proc. ASME Int. Mech. Eng. Congr. Expo. 2009, 8, 183-194. [CrossRef]

13. Gilbert, P.; Walsh, C.; Traut, M.; Kesieme, U.; Pazouki, K.; Murphy, A. Assessment of full life-cycle air emissions of alternative shipping fuels. J. Clean. Prod. 2018, 172, 855-866. [CrossRef]

14. Goldstein, L.; Hedman, B.; Knowles, D.; Freedman, S.I.; Woods, R.; Schwizer, T. Gas-Fired Distributed Energy Resource Technology Characterisations; Technical Report; Gas Research Institute and the National Renewable Energy Laboratory (NREL): Golden, CO, USA, 2003; p. 226. Available online: http:/ / www.osti.gov/bridge (accessed on 15 June 2021).

15. Project Guide Electronically Controlled Dual Fuel Two-stroke Engines. 2014. Available online: www.mandieselturbo.com (accessed on 20 November 2021).

16. Han, E.S.; Goleman, D.; Boyatzis, R.; Mckee, A. Basic Ship Theory, 5th ed.; Butterworth-Heinemann: Oxford, UK, 2001.

17. International Maritime Organization, Centre MK. International Shipping and World Trade Facts and Figures. 2009. Available online: https:/ / imo.libguides.com/MaritimeFactsandFigures (accessed on 20 November 2021). 
18. Jefferson, M.; Zhou, P.L.; Hindmarch, G. Analysis by computer simulation of a combined gas turbine and steam turbine (cogas) system for marine propulsion. J. Mar. Eng. Technol. 2003, 2, 43-53. [CrossRef]

19. Kakaç, S.; Liu, H.; Pramuanjaroenkij, A. Heat Exchangers: Selection, Rating, and Thermal Design, 3rd ed.; CRC Press: Boca Raton, FL, USA, 2012; p. 631. Available online: https://books.google.com/books?hl=en\&lr=\&id=sJXpvP6xLZsC\&pgis=1 (accessed on 10 July 2021).

20. Klassen, M. Fuel flexibility for dry low emission gas turbines-Cleanly burning biofuels, coal liquids and petroleum fuels. In Proceedings of the Power Gen International Conference, New Orleans, LA, USA, 10-14 December 2007.

21. Kumar, J.; Kumpulainen, L.; Kauhaniemi, K. Technical design aspects of harbour area grid for shore to ship power: State of the art and future solutions. Int. J. Electr. Power Energy Syst. 2019, 104, 840-852. [CrossRef]

22. Mohd Noor, C.W.; Noor, M.M.; Mamat, R. Biodiesel as alternative fuel for marine diesel engine applications: A review. Renew. Sustain. Energy Rev. 2018, 94, 127-142. [CrossRef]

23. Nalianda, D.K. Impact of Environmental Taxation Policies on Civil Aviation-A Techno-Economic Environmental Risk Assessment Supervisors; Cranfield University: Cranfield, UK, 2012.

24. Nikolaidis, T. The Turbomatch Scheme for Aero/Industrial Gas Turbine Engine. In Turbomatch Manual; Cranfield University: Cranfield, UK, 2015.

25. On, S.; Feasibilityuse, T.H.E.; Lng, O.F.; Shipping, F.F.O.R. Safe, Secure and Efficient Shipping on Clean Oceans Studies on the Feasibility and Use of LNG as a Fuel for Shipping. Air Pollution and Energy Efficiency Studies. 2016. Available online: www.imo.org (accessed on 20 July 2021).

26. Parks, S. Young carers. Br. J. Gen. Pract. 2014, 64, 616. [CrossRef] [PubMed]

27. Pilidis, P. Thermal Power Gas Turbine Performance; Cranfield University: Cranfield, UK, 2013; p. 175.

28. ENTEC. Ship Emissions Final Report. Quantification of ship emissions. Ship Emissions Final Report. 2002, pp. 3-48. Available online: http:/ / ec.europa.eu/environment/air/pdf/chapter2_ship_emissions.pdf (accessed on 10 August 2021).

29. Rivera-Alvarez, A.; Coleman, M.J.; Ordonez, J.C. Ship weight reduction and efficiency enhancement through combined power cycles. Energy 2015, 93, 521-533. [CrossRef]

30. Saravanamuttoo; Rogers, G.F.C.; Cohen, H.; Straznicky, P.V. Gas Turbine Theory. 2017. Available online: http://www.pearson. $\mathrm{com} / \mathrm{uk}$ (accessed on 10 July 2021).

31. Faulkner, L.L. Steam Generators and Waste Heat Boilers for Process and Plant Engineers; Taylor \& Francis Group: Abingdon, UK, 2015; pp. 39-89. [CrossRef]

32. Sayma, A.I. Gas turbines for marine applications. In Encyclopedia of Maritime and Offshore Engineering; John Wiley \& Sons: Hoboken, NJ, USA, 2017; pp. 1-10. [CrossRef]

33. Seebregts, A.J. Gas-fired power. IEA ETSAP_Technology. Brief E02. 2010, pp. 1-5. Available online: http://www.iea-etsap.org/ web/E-TechDS/PDF/E02-gas_fired_power-GS-AD-gct.pdf:2010 (accessed on 20 July 2021).

34. Spoof-Tuomi, K.; Niemi, S. Environmental and economic evaluation of fuel choices for Short Sea shipping. Clean Technol. 2020, 2, 4. [CrossRef]

35. Talluri, L.; Nalianda, D.K.; Giuliani, E. Techno economic and environmental assessment of Flettner rotors for marine propulsion. Ocean. Eng. 2018, 154, 1-15. [CrossRef]

36. Talluri, L.; Nalianda, D.K.; Kyprianidis, K.G.; Pilidis, P. Techno economic and environmental assessment of wind assisted marine propulsion systems. Ocean Eng. 2016, 121, 301-311. [CrossRef]

37. Tanuma, T. Advances in Steam Turbines for Modern Power Plants; Woodhead Publishing: Cambridge, UK, 2017.

38. Trozzi, C. Emission Estimate Methodology for Maritime Navigation. 2010. Available online: http://www.epa.gov/ttnchie1 /conference/ei19/session10/trozzi.pdf (accessed on 10 September 2021). 